\title{
The Impact on UK Acquirers of Domestic, Cross-Border, Public and Private Acquisitions
}

\author{
Robert L. Conn ${ }^{\mathrm{a}}$, Andy Cosh ${ }^{\mathrm{b}}$, Paul M. Guest ${ }^{\mathrm{c}}$, Alan Hughes ${ }^{\mathrm{d}}$ \\ ${ }^{a}$ Miami University, Oxford, Ohio, \\ ${ }^{\mathrm{b}, \mathrm{c}, \mathrm{d}}$ Centre for Business Research, University of Cambridge, Cambridge, U.K.
}

\begin{abstract}
We examine the announcement and post-acquisition share returns of 4,000 acquisitions by UK public firms during 1984-1998. We include acquisitions of domestic and cross-border targets, and of both publicly quoted and privately held targets. In acquisitions of domestic public targets, abnormal returns are negative over both the announcement and post-acquisition period. In acquisitions of cross-border public targets, abnormal returns are zero over the announcement period but negative over the postacquisition period. In contrast, acquisitions of both domestic and cross-border private targets result in positive announcement returns and zero long run returns. The main difference between private and public acquisitions is that glamour acquirers experience negative announcement and long run returns in public acquisitions, whereas glamour acquirers do not underperform in private acquisitions. Furthermore, whereas the underperformance of domestic public acquisitions is limited to acquirers using noncash methods of payment, acquirers of domestic private targets that use noncash methods do not underperform. Overall, cross-border acquisitions result in lower announcement and long run returns than domestic acquisitions. In cross-border acquisitions involving hightech firms both announcement and long run returns are positive, whilst non-high-tech cross-border acquisitions experience zero announcement returns followed by negative long run performance. Our results also suggest that, in cross-border acquisitions, the national cultural difference between the bidder and target countries has a significantly negative impact on long run returns.
\end{abstract}

Keywords: acquisitions, takeovers, announcement returns, long run returns, cross-border targets, private targets

Acknowledgements: We are grateful for comments provided by seminar participants at Cambridge University, Vienna University, the 2001 EARIE Conference in Dublin, and the 2002 EFMA Conference in London. We are particularly grateful to an anonymous referee, Paul Laux, Dennis Mueller, Ajit Singh and Burcin Yurtoglu for insightful comments and discussion. 


\section{Introduction}

Compared to earlier merger waves, the waves of the 1980s and 1990s were distinct in terms of the amount of cross-border acquisition activity. On a global scale, cross-border acquisitions worldwide during 1986-2000 accounted for $26 \%$ of the value of total acquisitions. The global value of cross-border acquisitions rose steadily from about $0.5 \%$ of world wide GDP in the mid1980s to being over $2 \%$ in 2000 . Clearly, cross-border acquisitions are more prevalent and bigger than ever before, and now account for over $80 \%$ of all foreign direct investment by industrialised countries (UNCTAD, 2000).

Within this global trend, UK acquiring companies have played an increasingly important role. As shown in Figure 1, both the number and value of cross-border acquisitions by UK companies increased dramatically in the mid-1980s and 1990s, and were approximately equal to the number and value of domestic acquisitions over this period. The value of cross-border acquisitions carried out by UK companies accounts for an increasing proportion of all worldwide cross-border acquisitions. By 2000, the UK was the largest acquiring country worldwide, accounting for $31 \%$ of the total value of all cross-border acquisitions (UNCTAD, 2000).

An important aspect of the UK acquisition activity abroad is the acquisition of privately held companies. Over the period 1985-98, $94 \%$ of the number of cross-border acquisitions was for privately held targets. In terms of total expenditure, $58 \%$ of the value of cross-border acquisitions was for privately held targets, reflecting the smaller size of private acquisitions. For domestic acquisitions, $88 \%$ of their number and $25 \%$ of their value are accounted for by acquisitions of privately held targets. ${ }^{1}$ Acquisitions of private targets therefore account for the vast majority of acquisitions made by UK companies in terms of number, and approximately half in terms of value.

1 Based on figures from Acquisitions Monthly, representing all acquisitions made by all UK companies (public and private), in which the transaction value is disclosed. This source reports that the vast majority in terms of both number (85\%) and value (87\%) of domestic and cross-border acquisitions by UK companies are carried out by publicly held companies. 


\section{Insert Figure 1 here}

Despite the scale of acquisitions involving cross-border targets and targets which are not publicly quoted, nearly all acquisition studies are limited to acquisitions of domestic targets which are publicly quoted. These studies have typically found that acquiring shareholders earn neutral or negative returns over the short run announcement period. ${ }^{2}$ While these announcement period returns are important sources of information, the possibility exists that the market does not always accurately predict the future performance of acquisitions. Hence, an evaluation of the long run performance is also warranted. The long run post-acquisition studies have found mixed results with some finding negative returns, some studies finding zero returns. ${ }^{3}$ However, there are important theoretical reasons (discussed in the next section of the paper) why acquisitions of cross-border targets may differ from acquisitions of domestic targets, and why acquisitions of private targets will differ from acquisitions of public targets. It is therefore important to examine the performance of these different types of acquisitions. We do so by examining the announcement period and three-year post-acquisition performance of a sample of over 4,000 acquisitions by UK public firms occurring during 1984-1998.

The paper differs from previous long run merger studies in two important respects. Firstly, the study includes acquisitions of both domestic and cross-border targets, and acquisitions of both publicly quoted and privately held targets. No previous long run event study has examined all of these four different types of acquisition. This comprehensive sample allows each acquisition type to be directly contrasted with one another, and permits us to reach conclusions on the long run wealth effects of all acquisitions made by public acquirers. Secondly, this study utilises a long run methodology robust to most recent criticisms of commonly used long run methods (Mitchell and Stafford, 2000), which although used in domestic acquisitions has not yet been employed in cross-border acquisitions. The calendar time methodology (Jaffe, 1974; and Mandelker, 1974) we

2 See Andrade et al. (2001), and Sudarsanam and Mahate (2003).

3 These studies are reviewed in Agrawal and Jaffe (2000), and Andrade et al. (2001). 
employ explicitly accounts for statistical problems caused by the lack of independence among observations, arising from overlapping returns and the non-random timing of acquisitions (Lyon et al., 1999).

There are several major findings of the study. Acquisitions of private targets (domestic and cross-border) outperform acquisitions of public targets over both the announcement and threeyear post merger period. Acquisition of domestic public targets result in significantly negative announcement returns of $-0.99 \%$ and significantly negative returns in the three years after merger of $-22 \%$. Acquisition of cross-border public targets result in zero announcement returns but significantly negative returns in the three post-acquisition years of $-32 \%$. Acquisition of private targets, either domestically or internationally, result in significantly positive announcement returns and zero long run returns. The long run findings are robust to alternative methods such as calendar time abnormal returns.

We find that the main difference between private and public acquisitions is that glamour acquirers experience negative announcement and long run returns in public acquisitions, whereas there is no evidence of this in private acquisitions. Furthermore, whereas the underperformance of domestic public acquisitions is limited to acquirers using noncash methods of payment, acquirers of domestic private targets that use noncash methods do not underperform. In contrast, in crossborder public acquisitions the method of payment has no significant influence on performance. One interpretation of this finding is that domestic acquirers offer overvalued securities, but that the increased due diligence and monitoring in cross-border mergers reduces the importance of method of payment.

Overall, cross-border acquisitions result in lower announcement and long run returns than domestic acquisitions. In cross-border acquisitions involving high-tech firms both announcement and long run returns are positive, whilst non-high-tech cross-border acquisitions experience zero announcement returns followed by negative long run performance. Thus, the internalization theory of cross-border mergers is supported by our findings. Our results also suggest that, in 
cross-border acquisitions, the national cultural difference between the bidder and target countries has a significantly negative impact on long run returns. However, we fail to find support for some of the most common explanations for cross-border mergers, such as differences in legal systems, accounting standards, taxes, or exchange rates.

The paper is organised as follows: The next section discusses the determinants of returns in acquisitions of cross-border targets and privately held targets. Section 3 reviews the existing empirical evidence. Section 4 describes the data, sample characteristics, and methodology. Section 5 presents the returns for the entire sample. Section 6 investigates the determinants of announcement and post-acquisition returns. The final section concludes.

\section{Hypotheses on acquisitions of cross-border and private targets}

\section{(i) Information based assets and the returns from cross-border acquisitions ${ }^{4}$}

One important argument for expecting the returns from cross-border acquisitions to be higher than those in domestic acquisitions is based on the gains from diversification when businesses seek synergies arising from intangible and especially information based assets (Baldwin and Caves, 1991; and Morck and Yeung, 2003). Examples of intangible information-based assets are brand names, specific assets in the form of technical knowledge, and R\&D expenditure. In crossborder mergers geographic diversification by direct investment in overseas subsidiaries permits firms to expand the boundary of the firm. This expansion permits the internalization of synergies

4 For a careful review of these and related effects in cross-border acquisitions, see Conn (2003). The general argument in relation to intangible and information based assets is crisply summarised in Baldwin and Caves (1991). Another set of arguments in cross-border acquisitions relate to factors affecting the rate or direction of overseas acquisitions over time or between countries as opposed to factors affecting the relative returns from domestic and overseas acquisitions given those factors. Examples of work in the former vein include Froot and Stein (1991) who argue that overseas acquisitions from a country will be higher when its exchange rate is strong because cross-border acquirers will then have a comparative advantage over local bidders, and Scholes and Wolfson (1990) who posit that tax law changes in the 1981 Economic Recovery Act put foreign buyers in the US at a comparative disadvantage to domestic acquirers. This they argue was due to increased incentives for domestic mergers arising from more accelerated depreciation allowances and lower corporate tax rates. Similarly, the modification of some of the tax- 
based on intangible information based assets that would otherwise be lost because of various market failures. There are several kinds of market failure, which prevent arms length transactions from extracting the full synergistic value from the use of these assets (see e.g. Teece et al., 1997). Examples include difficulties in transmitting information and knowledge when it is tacit rather than codified, the 'lemons problem' when information asymmetry prevents a seller from obtaining the true value of the asset, and hold-up problems for one party to a deal where investments in specific assets are required to complement an input purchased from the other firm. An acquisition internalises these transactions and overcomes the market failure. Internalization, by geographical diversification, of transactions involving information-based assets thus permits the exploitation of economies of scale and scope in those assets. The tendency for cross-border acquisitions to be more prevalent in industries with high levels of R\&D and technological inputs, and for multinational firms to earn higher than average rates of return is consistent with this interpretation of the gains from geographical diversification (Caves, 1986; Morck and Yeung, 2003; and UNCTAD, 2000).

(ii) Imperfect information, post-merger integration and the returns from cross-border acquisitions

Whilst internalization theory provides an argument for expecting higher returns in crossborder than domestic acquisitions, a number of factors point in the opposite direction. One group of reasons is based on the idea that overseas targets are more difficult to value accurately because of imperfect information. This type of argument is most frequently used in relation to acquisitions by UK and US firms of businesses in countries with less well-developed capital markets. This argument may also point to the prediction that the variance of returns should be higher in cross-

related benefits in the 1986 Tax Reform Act is argued to have reduced the competitive disadvantage of foreign buyers in the US We return to these arguments briefly in Section 6 below. 
border deals. ${ }^{5}$ Another set of reasons for expecting relatively poor returns arises from difficulties of managing the post-merger process when cultural differences make integration and acculturation a difficult, time consuming and expensive process. The bigger the cultural gap and the bigger the relative size of the target the worse the problems may be. These problems clearly affect cross-border as opposed to domestic acquisitions. ${ }^{6}$

\section{(iii) Acquirer returns; the method of payment and the private/public company divide}

The theoretical and empirical literature on acquisition activity in general suggests that a number of characteristics of the bid may affect bidder returns. There is for instance evidence for positive impacts on acquirer performance for industry relatedness, hostility, and relative size (Mitchell and Stafford, 2000; Cosh and Guest, 2001; Fuller et al., 2002; and Megginson et al., 2004).

This literature is in general well-known and we do not rehearse it here except to note that if, for whatever reason, a sample of cross-border mergers differs from domestic mergers in these dimensions then performance differences may follow. It is necessary therefore to control for these effects when attempting to isolate public, private, domestic and international impacts. Another strand of the acquisition literature has emphasised the impact upon acquirer returns of methods of payment and the public or private status of the target. Since we believe that this has particular implications for international acquisition behaviour it is worth discussing a little more fully here.

5 A different capital market thesis pointing to relatively high gains is advanced by La Porta et al. (2000). They argue that investor protection is highest in English common law countries, followed by the Scandinavian, Germanic and French civil law countries, and that efficient cross-border acquisitions will take place when an acquirer from a high investor protection country acquires a target from a low investor protection country. In a different vein, Moeller and Schlingemann (2002) argue that acquisition performance may be lower in more restrictive institutional environments, because of greater asymmetric information.

6 Evidence from the human resource, organisational behaviour and strategic management disciplines as well as practitioner surveys suggest that national culture is an important determinant of success in crossborder acquisitions (Baldwin and Caves, 1991; Schoenberg, 2000; and UNCTAD, 1999). An excellent overview of this literature and an empirical application to inward takeovers in the UK is Child et al. (2001). 
Bids for private firms are, as we have seen, a major component of both domestic and overseas acquisition activity. There are arguments for believing that bids for such firms may lead to bidder returns that exceed those obtained in bids for public firms. The first argument is that the process of making private bids is less exposed to public gaze. Bidders can end negotiations without the loss of face that may occur in a public bid, especially if the public bid is hostile. Poor acquisition outcomes due to hubris are therefore less likely in private bids. Secondly in a private bid, if the payment is in shares, and if the target is relatively large compared to the bidder, then since the target management are typically majority shareholders in private firms they can end up as significant blockholders in the post merger firm. They may then play a monitoring role in ensuring that post merger activities are in the stockholders interests generally. Equally, they have a greater incentive to exercise due diligence prior to the bid. Thirdly, the private nature of the transaction may lead to the disclosure of information between the parties which would be impossible in a public bid where, frequently, takeover codes and listing rules require equal and public information disclosure to all shareholders. Finally, the illiquid nature of the market in the closely-held stock of private firms may make less likely the emergence of competing bids. The payments of the significant premia which characterise contested public acquisitions are therefore less likely and bidder returns are more likely to be positive as a result of this 'discount'.?

There are a number of reasons for expecting the method of payment to vary in cross-border compared to domestic bids and especially in private compared to public bids. The usual argument for method of payment effects is that cash bids do better for bidder shareholders because the market takes this as a positive signal of bidder expectations of future returns. ${ }^{8}$ This argument may

7 Fuller et al. (2002), Ang and Kohers (2001), Moeller and Schlingemann (2002), and Moeller et al. (2004), provide useful overviews of these arguments. The empirical evidence on the existence of a private sector discount is mixed. Koeplin et al. (2000) find that private companies sell for a significant discount compared to public companies. Ang and Kohers (2001) on the other hand, find that private targets sell for a significantly higher premium than public targets.

8 See for example Loughran and Vijh (1997). There are two alternative explanations for the positive impact of cash bids. One is the signalling argument that acquirers offer securities when they are overvalued (Myers and Majluf, 1984). The other explanation is that acquirers offer securities when they have a low valuation of the target (Fishman, 1989). 
not have the same force in the case of cross-border bids, because other factors will also influence the means of payment. For example, the use of equity by cross-border acquirers may be due to the greater uncertainty connected with the information problems associated with acquiring abroad. This may be especially true for private overseas deals where the information may be even more imperfect. If bidder shareholders recognise this reasoning then the usual positive impact of cash bids compared to equity bids may be nullified. Equally, cash bids may be forced by the reluctance on the part of cross-border target shareholders to accept foreign equity (Gaughan, 2002). In this case too the signalling impact of the use of cash may be neutralised. This neutralising effect may be present too in the case of private bids generally if the over-riding objective of target owner managers is to "cash out" rather than stay on as stakeholders in the newly enlarged firm. The positive impact of cash on returns may therefore be less apparent in bids for overseas public firms than in bids for domestic public firms and less apparent in bids for private than for public companies generally.

\section{Previous research on returns to shareholders of bidding firms}

\section{(i) Empirical evidence on bidder returns: acquisitions of cross-border targets}

There is extensive empirical evidence on the short run announcement period returns to acquiring company shareholders in cross-border acquisitions of publicly quoted targets. Conn (2003) reports that of the 15 studies he reviews, the primary conclusion is the dominance of zero or negative cumulative abnormal returns (CARs) for acquiring firms (both US and UK). These findings closely parallel those observed in domestic acquisitions of public targets for both the US (Andrade et al., 2001) and the UK (Sudarsanam and Mahate, 2003). 
There is limited empirical evidence on long horizon share returns in cross-border acquisitions. ${ }^{9,} 10,11$ Table 1 summarises the results of the six long run studies to date for both US and UK acquirers. A drawback with four of the studies (Conn and Connell, 1990; Danbolt, 1995; Eckbo and Thorburn, 2000; and Aw and Chatterjee, 2004) is their use of the market model methodology, the weaknesses of which are now well documented. Market models suffer from parameter instability (Coutts et al., 1997), are inferior to multi index models (Fama and French, 1992), and are subject to statistical biases which have led to more reliable test statistics being employed than those employed in these studies (Lyon et al., 1999). However, the two studies by Black et al. (2003) and by Gregory and McCorriston (2004) do address some of these methodological concerns.

\section{Insert Table 1 here}

The four studies by Conn and Connell (1990), Danbolt (1995), Black et al. (2003), and Aw and Chatterjee (2004), examine cross-border acquisitions of publicly quoted targets. Despite the variation in methodology and sample, all four studies report significantly negative postacquisition returns. Aw and Chatterjee (2004) directly compare cross-border with domestic acquisitions, and find that in cross-border acquisitions returns are lower although not significantly so. The studies by Eckbo and Thorburn (2000) and by Gregory and McCorriston (2004) examine cross-border acquisitions of both publicly and privately held targets. In contrast to the other crossborder long run studies, neither study finds evidence of significantly negative long run returns. Neither study reports returns separately for public and private acquisitions.

9 In terms of profitability effects, Eckbo and Thorburn (2000) find a significantly negative impact of cross-border acquisitions on earnings, but not domestic acquisitions. Similarly, Moeller and Schlingemann (2002) find a significantly lower change in operating performance for cross-border acquisitions compared to domestic acquisitions.

10 There is a large literature examining the impact of multinationality on firm value, the results for which are mixed. For example, Denis et al. (2002) find a negative impact, whilst Bodnar et al. (1997) find a positive impact.

11 A recent practitioner survey found that shareholder value decreased in $53 \%$ of 700 cross-border acquisitions completed during 1996-98 (Kelly et al., 1999). 
The tentative overall conclusions one draws from these six studies is that cross-border acquisitions of all public and private targets do not result in significantly negative long run returns, whereas cross-border acquisitions of targets which are publicly quoted do result in significantly negative long run returns.

\section{(ii) Empirical evidence on bidder returns: acquisitions of private targets}

There is very little evidence on either the short or long run returns to public acquirers that acquire privately held targets. Chang (1998) finds no significant announcement period returns for bidders that acquire private targets with cash, whilst bidders that use stock have a significantly positive return. In contrast, bidders that acquire public targets with stock have a significantly negative return. Hansen and Lott (1996) find that bidders experience a two percent higher return when purchasing a private firm compared to a public firm. Similarly, Fuller et al. (2002) find that bidder shareholders gain when buying a private firm or subsidiary but lose when purchasing a public firm. Moeller et al. (2004) report positive abnormal announcement returns for acquisitions of subsidiaries and independent private firms and negative returns for public targets. Therefore, the short run evidence suggests generally higher returns for US buyers in domestic purchases of privately held targets than for purchases of publicly held targets.

Two recent US studies examine the effects of private acquisitions on the acquirers' long run stock performance. Both Ang and Kohers (2001) and Moeller et al. (2004) use the Fama-French three-factor model, and find no evidence of abnormal returns in the three-year post acquisition period. The same result holds for subsamples of cash offer bids and stock offer bids. ${ }^{12}$

12 In terms of operating performance, Moeller and Schlingemann (2002) find a positive but insignificant effect of private acquisitions compared to public acquisitions. 


\section{Data, sample statistics and methodology}

\section{(i) Data}

We examine a sample of acquisitions of domestic public, domestic private, cross-border public, and cross-border private target companies by UK public companies, completed between January 1, 1984 and December 31, 1998. The sample acquisitions are drawn from the Thomson Financial SDC Mergers Database and the Thomson Financial magazine Acquisitions Monthly. ${ }^{13}$ Acquisitions are defined as occurring when the bidder owns less than $50 \%$ of the target's voting shares before the takeover, and increases its ownership to at least $50 \%$ as a result of the takeover. We exclude acquisitions if the UK bidder is not a publicly traded firm with its share price data held on the Datastream Database. Many acquisitions involve relatively small targets that may not be expected to have a material effect on the acquirer. We therefore adopt a materiality constraint that limits our sample to acquisitions in which the target's acquisition value is at least $5 \%$ of the acquiring firm's market value in the acquisition month. We exclude acquisitions for which the acquisition value was not reported. Our final sample of 4,344 acquisitions consists of 131 acquisitions of cross-border public targets, 1,009 acquisitions of cross-border private targets, 576 acquisitions of domestic public targets, and 2,628 acquisitions of domestic private targets.

\section{(ii) Sample statistics}

Table 2 highlights salient features of the samples according to whether the target is a domestic or cross-border company, and a public or private company. Firstly, consistent with the aggregate figures above, private targets are more numerous than public targets but also much smaller in both absolute and relative values compared to bidders. Secondly, two thirds of the sample

13 Of our sample of 4,344 acquisitions, 2,538 are drawn from Acquisitions Monthly, whilst 3,989 are drawn from SDC, with an overlap between the two databases of 2,182 acquisitions. The Acquisitions Monthly data does not suffer from survivorship bias because it is hand collected from a monthly magazine that is published at the end of the announcement month. Similarly, the SDC data includes acquisitions by 
acquirers engaged in multiple acquisitions during the sample period 1984-1998, with an average number of five acquisitions. Multiple acquisitions raise the problem of dependent observations due to overlapping observations, and we return to this issue below. Third, cash is the primary medium of payment in cross-border acquisitions and in private acquisitions. The most prevalent use of stock is found in domestic acquisitions of public targets. Fourth, the proportion of hostile acquisitions is about $10 \%$ for cross-border acquisitions of public targets and $13 \%$ for domestic deals with public firms. Thus, friendly acquisitions dominate our samples. Fifth, acquisitions between firms in related industries (defined as the same 2-digit SIC code) occur in $45 \%$ of the cross-border sample and 39\% of the domestic sample, although the proportions are significantly higher in acquisitions of private targets compared to public targets. Sixth, acquisitions involving high-tech firms as either the target or bidder are significantly more common in cross-border acquisitions. ${ }^{14}$ This is consistent with the internalization theory for cross-border acquisitions and is consistent with Harris and Ravenscraft (1991). Finally, the major targets of cross-border acquisitions are in North America (53\%) and Europe (40\%). Thus, UK acquirers have a clear preference for targets in industrialised countries and English speaking countries.

Insert Table 2 here

(iii) Methodology

\section{(a) Announcement period returns}

We follow Brown and Warner's (1985) standard event study methodology to calculate cumulative abnormal returns (CARs) for the 3-day period $(-1,1)$ around the announcement date.

acquirers that subsequently die. We are confident therefore, that our sample of acquirers does not suffer from survivorship bias.

14 Butchart (1987) defines UK industries as high-tech if the R\&D expenditure to industry output is substantially above average. If this ratio is above - but not substantially above - average, a second measure is employed based on the proportion of scientists, professional engineers and technicians in the labour force. The following UK SIC 2-digit industries are subsequently classified as high-tech: Chemicals (SIC 24), Plastics (SIC 25), Machinery and Equipment (SIC 29), Office Machines and Computers (SIC 30), 
The abnormal returns are estimated using the market-adjusted model, where the benchmark return is the contemporaneous return on the Datastream equal weighted market index. The $t$-statistics are estimated using the cross-sectional variation of abnormal returns. We do not estimate market parameters based on a time period before each bid since our sample acquirers make frequent acquisitions and there is a high probability that previous takeover attempts would be included in the estimation period thus making beta estimations less meaningful. Additionally, it has been shown that for short-window event studies weighting the market return by the firm's beta does not significantly improve estimation (Brown and Warner, 1980).

The three-day window is one of the two most commonly used event windows for merger studies (Andrade et al., 2001). The other window most commonly used starts before the announcement and ends with the completion of the merger. ${ }^{15}$ The longer window makes it possible to take into account bid revisions and competition. The advantage of the shorter window used here is that its results are typically insensitive to the model chosen for expected returns. ${ }^{16}$

\section{(b) Post-bid period returns}

The selection of a proper benchmark is always problematic when examining long run returns. Lyon et al. (1999) show that differences in the properties of sample and population distributions can create biases and ambiguities in test statistics. Table 2 shows that acquirers tend to be distributed in the higher size and market-to-book ratio quintiles. Our counterfactual approach therefore measures acquirer performance relative to non-acquiring control firms matched on size and market-to-book ratio. The control firms are selected by first dividing all UK stocks listed on Datastream into ten equal sized portfolios based on their market values at the beginning of each

Electrical Equipment (SIC 31), Electronics (SIC 32), Medical Instruments and Control Equipment (SIC 33), Telecommunications and Post (SIC 64) Software (SIC 72), and R\&D (SIC 73).

15 For our sample, the average length of time between the announcement date and the completion date is 14 days.

16 We also calculate abnormal returns over the entire announcement month using a size/market-to-book control firm benchmark (as described in the next section). Our results are not sensitive to either definition of abnormal returns. 
calendar year. Those control firms that carried out a sample acquisition within the preceding or subsequent five years are then excluded from the matching universe. Each sample firm is then matched with the non-merging firm from its size portfolio that has the closest market-to-book ratio at the beginning of the calendar year. This procedure is repeated for each post-takeover calendar year using a fresh grouping by size decile for the year in question. ${ }^{17}$ The control firm approach avoids the skewness and rebalancing biases inherent in a reference portfolio. The skewness bias arises if the distribution of long run abnormal stock returns is positively skewed. ${ }^{18}$ The rebalancing bias arises because the compound returns of a reference portfolio, such as an equally weighted market index, are typically calculated assuming periodic rebalancing. ${ }^{19}$

We adopt two approaches to measure long run abnormal stock-price performance. First, we follow the approach of Barber and Lyon (1997) and estimate buy-and-hold abnormal returns (BHARs), beginning the month following completion through the end of the 36-month period following the completion month, or until the sample firm is delisted. As pointed out by Fama (1998) and Mitchell and Stafford (2000), estimating statistical significance with this methodology is problematic because standard $t$-statistics do not adequately account for potential cross-sectional dependence in returns. In particular, standard errors will be biased downwards and $t$-statistics will be biased upwards. This is a real problem for our sample because only a small number (502) of our sample acquisitions are carried out by single acquirers, and the remaining 3,842 sample acquisitions are accounted for by 974 acquirers, an average of five per acquirer. The time between acquisitions for multiple acquirers is on average 14 months meaning that many acquisitions will overlap with another acquisition by the same acquirer. To address this problem, we firstly calculate $t$-statistics which are adjusted for cross-sectional dependence using an identical method

17 If a control firm dies within the year, we replace the returns from the month of exit with the returns of the next nearest firm in terms of market-to-book ratio within the particular size decile at the beginning of the year in which the exit took place. If this control firm dies then we use the next closest firm, and so on.

18 Examination of the distribution of abnormal returns revealed no evidence of skewness (skewness statistic -0.47), and therefore no need for skewness adjusted $t$-tests. 
to Mitchell and Stafford (2000). ${ }^{20}$ The advantage of this method is that it allows us to attach statistical significance to buy-and-hold returns, which are an accurate representation of investor experience.

The alternative approach follows Fama (1998) and Lyon et al. (1999), who recommend using the Jaffe (1974) - Mandelker (1974) calendar time portfolio technique to overcome crosssectional dependence. In each calendar month we form a portfolio of event firms, and take the average cross-sectional abnormal return for that month. The average abnormal return for the entire sample is the time series average (CTAR) and the $t$-test is calculated using the standard deviation of the time series. ${ }^{21}$ This $t$-test is shown by Lyon et al. (1999) as not biased in the presence of overlapping returns.

\section{The stock returns for our sample}

\section{(i) Announcement returns}

We begin our results by examining acquirer announcement returns as measured by the CAR over the announcement period, as reported in Table 3. Both domestic and cross-border

19 However, our approach is susceptible to the new listing bias, which arises because some of our control firms may have begun trading subsequent to the announcement month. Generally, the new listing bias creates a positive bias, because newly listed firms tend to underperform.

20 The $t$-statistics are adjusted using the following approximation for the standard deviation:

$$
\sigma_{\mathrm{BHAR}}(\text { independence }) / \sigma_{\mathrm{BHAR}}(\text { dependence }) \approx 1 / \sqrt{ } 1+(N-1) \rho_{i, j}
$$

where $\sigma_{\mathrm{BHAR}}=$ standard deviation of individual BHARs, $N=$ number of sample events and $\rho_{i, j}=$ average correlation of individual BHARs. To estimate $\rho_{i, j}$, we firstly calculate average pairwise correlations of annual BHARs for all acquirers that complete acquisitions in the same month, and thus have 36 months of calendar time overlap. The grand average of these average pairwise correlations is 0.008 . We then assume that the average correlation for overlapping observations is linear in the number of months of calendar time overlap, ranging from zero for non-overlapping observations to the estimated average correlation of 0.008 for acquirers with complete overlap. This gives a $\rho_{i, j}$ of 0.002 . To the extent that average correlations are increasing in the holding period, the correlation of three-year BHARs will be higher than the annual correlations calculated here, and therefore the standard errors are still likely to be understated (Mitchell and Stafford, 2000).

21 Our announcement and post-acquisition return measures reveal the short term reaction to takeover and any long term market revisions, but do not precisely measure the overall performance (announcement plus post-acquisition returns) and its significance. In order to estimate overall performance we estimate the calendar time approach including the abnormal return for the announcement month as well as the 36 postacquisition months. These overall calander time returns are very similar to the post-acquisition returns 
acquisitions result in significantly positive returns of $0.68 \%$ and $0.33 \%$, respectively. However, the positive returns are driven by mergers with private targets rather than public targets. In domestic mergers the returns for acquiring public firms are a significantly negative $-0.99 \%$, whilst the returns for acquiring cross-border public targets are an insignificant $-0.09 \%$. In contrast, the returns for private targets are significantly positive. Acquisitions of private firms result in significantly positive returns of $0.38 \%$ in cross-border acquisitions and $1.05 \%$ in domestic acquisitions. For all public acquisitions, returns are a significantly negative $-0.82 \%$, compared to a significantly positive $0.86 \%$ in all private acquisitions.

The significantly negative returns to acquirers in domestic acquisitions of public targets are consistent with previous studies (Sudarsanam and Mahate, 2003). The insignificant negative returns in cross-border public acquisitions are not surprising given the mixed findings in previous studies (Conn, 2003). However, the finding of significantly positive gains in domestic private acquisitions is consistent with previous evidence for the US (Hansen and Lott, 1996; and Fuller et al., 2002). This is the first evidence that returns in cross-border acquisitions are positive for private targets and zero for public targets.

Insert Table 3 here

(ii) Post-acquisition stock returns

(a) Buy-and-hold returns

Panel A of Table 4 reports the buy-and-hold abnormal returns for the 36 months following the completion of the acquisition. We observe a clear difference in returns between public acquisitions and private acquisitions, in both the cross-border and domestic samples. Domestic acquisitions of public targets result in significantly negative returns of $-19.78 \%$. Cross-border acquisitions of public targets result in returns of $-32.33 \%$. The return for acquisitions of all

reported, and therefore our main conclusions on post-acquisition performance can be interpreted as 
publicly quoted targets is a significantly negative $-22.11 \%$. In contrast, there is no evidence of significantly negative returns in acquisitions of private targets. Domestic acquisitions of private targets result in insignificant negative returns of $-4.78 \%$, whilst cross-border acquisitions of private targets result in insignificant negative returns of $-10.91 \%$. The return for all cross-border and domestic acquisitions of private targets is an insignificant $-6.48 \%$. For all cross-border acquisitions the return is $-13.37 \%$, which is significant at the $10 \%$ level. For all domestic acquisitions the return is an insignificantly negative $-7.47 \%$, and for all acquisitions it is an insignificantly negative $-9.02 \%$.

\section{Insert Table 4 here}

For our event time returns, we have used BHARs as recommended by Lyon et al. (1999). However, Fama (1998), who favours CARs, notes that BHARs grow with the return horizon even if there is no abnormal return after the first period. We therefore recalculated the tests in Panel A of Table 4, using CARs instead of BHARs but found no significant differences between the two techniques. ${ }^{22}$

\section{(b) Calendar time returns}

Panel B of Table 4 reports the monthly CTARs for the 36 months following the completion of the acquisition. Domestic acquisitions of public targets result in significantly negative returns of $0.40 \%$, indicating that these acquirers exhibit average abnormal returns of $-0.40 \%$ per month over the 36-month period following the acquisition. Cross-border acquisitions of public targets result in significantly negative returns of $-0.71 \%$. The return for acquisitions of all publicly quoted targets is a significantly negative $-0.42 \%$. This translates to a compounded three year return of approximately $-14.06 \%$, which is somewhat lower than the BHAR of $-22.11 \%$ reported in Panel

A.

representing overall performance as well.

22 The results are available from the authors on request. 
Cross-border acquisitions of private targets result in insignificant negative returns of $-0.19 \%$, whilst domestic acquisitions of private targets result in insignificant negative returns of $-0.08 \%$. The return for all acquisitions of private targets is $-0.14 \%$. This translates to a three-year return of approximately $-4.92 \%$, which is close to the negative BHAR of $-6.48 \%$ reported in Panel A. For all cross-border acquisitions, the return is an insignificantly negative $-0.27 \%$. For the domestic acquisitions, the return is an insignificantly negative $-0.19 \%$. The CTAR results are therefore quite similar to the BHARs, both in terms of magnitude and statistical significance.

Loughran and Ritter (2000) suggest that CTARs lack power because they weight each month equally regardless of the number of observations in that month, and are therefore inferior to BHARs. To check the robustness of our results, we recalculated the CTARs by weighting each calendar month by the number of observations in that month, but found no significant differences in our findings. ${ }^{23,24}$

We have identified several patterns in the long run returns which are robust to using either buy-and-hold or calendar time returns, and are consistent with the empirical long run studies reviewed in Section 3. Firstly, acquisitions of domestic public and cross-border public companies both exhibit significantly negative returns. Secondly, acquisitions of domestic private companies and cross-border private companies, both exhibit insignificant returns. Thirdly, acquisitions of all domestic companies, which include both public and private targets, exhibit insignificant returns. Fourthly, returns in cross-border acquisitions are slightly lower than in domestic acquisitions. For the sample of all cross-border acquisitions, weak evidence of negative returns is shown using the buy-and-hold $t$-statistic but not the calendar time $t$-statistic. We consider the latter to be the more reliable methodology because of the difficulty in estimating the true correlation of three-year

23 The results are available from the authors on request.

24 Our results are unchanged when we use only one acquisition per firm per calendar month in each category of acquisition. 
BHARs, and hence the true standard errors. Consequently, in Section 6 below, which investigates the determinants of long run returns, we report results based on calendar time abnormal returns. ${ }^{25}$

\section{The determinants of acquisition returns}

In this section, we move from the measurement of average outcomes to examine the determinants of announcement and long run returns. The purpose of this part of the paper is to examine whether the differences we have found between domestic and cross-border, and between public and private acquisitions, are still found when we take account of other factors which are known to influence merger outcomes. In Section 6(i) we employ univariate analysis and in Section 6(ii) we employ regression analysis.

\section{(i) Univariate analysis}

(a) Returns by method of payment and relative size

Table 5 reports the returns to acquirers classified by type of target, method of payment and relative size. This is important in view of our finding, shown in Table 2, that cross-border acquisitions are dominated by cash, and that within domestic acquisitions, private targets are far more likely to be acquired by cash. Table 5 allows us to distinguish the domestic/cross-border and the public/private from the cash/noncash effects. Acquisitions are categorised according to whether the acquisition is made with an all cash offer, or any other offer. Noncash offers include stock offers, stock and cash offers, and other offers.

The impact of the method of payment is examined for announcement returns in Panel A of Table 5. The announcement abnormal returns reveal that in nearly all cases, cash deals are worse than noncash deals. The exception is domestic public acquisitions, for which the insignificant positive announcement returns associated with cash acquisitions exceed the significantly negative

25 We carried out the analysis in Section 6 using buy-and-hold returns instead of calendar time returns. 
noncash acquisitions. In every category of payment method, public targets give lower announcement returns than private acquisitions.

Panel B reports the calendar time returns for the post-bid 36 months. In acquisitions of public targets financed by cash, returns are an insignificant $0.06 \%$. In contrast, if such acquisitions are financed by noncash, returns are a significantly negative $-0.47 \%$. In acquisitions of private targets, returns are small and insignificant regardless of whether the payment is cash $(-0.14 \%)$ or noncash $(-0.07 \%)$. Therefore, we find the main difference between the long run performance of domestic private and public acquisitions is the worst performance of public targets in domestic noncash acquisitions.

In assessing the returns for cross-border acquisitions, we should recall that Table 2 showed $80 \%$ of cross-border acquisitions of public targets to be cash financed. These acquisitions result in large negative returns of $-0.59 \%$, significant at the $10 \%$ level. The very small sample of 26 noncash public acquisitions exhibit negative although insignificant returns of $-0.51 \%$. In acquisitions of private targets, returns are insignificantly negative for both cash $(-0.19 \%)$ and noncash $(-0.32 \%)$.

\section{Insert Table 5 here}

Our results show that acquisitions of domestic public targets financed by noncash methods result in significantly negative long run returns, whereas those financed by cash do not, consistent with previous studies (Loughran and Vijh, 1997). In contrast, in cross-border acquisitions of public targets, we find weak evidence of negative returns in both cash and noncash financed deals. In line with these findings, Black et al. (2003), report that cross-border public acquisitions underperform, regardless of whether cash or stock is used. Since shareholders of foreign companies may be reluctant to receive securities as the method of payment, one possibility is that overvalued acquirers or acquirers with a low value of the target are forced to offer cash instead of

This made no material difference to our results or our conclusions. 
securities. In contrast to public acquisitions, we find no evidence that acquisitions of private targets which are financed by noncash experience negative returns.

One explanation for the latter finding is the theory that private acquisitions perform well because target shareholders become effective monitors in the acquirer. This theory implies that returns in noncash acquisitions should be increasing in the relative size of the target (Fuller et al., 2002). We define relative size by the ratio of the value of the deal to the market value of the acquirer. We find consistent support for this hypothesis only for private targets. Amongst most other groups, targets of a larger relative size have a worse impact on both announcement and long run returns. This is generally the case for cash offers, but is also found for noncash, public offers. $^{26}$ The findings are not reported in detail here, but are explored in Section 6(ii). We therefore find little evidence to suggest that improved monitoring can explain the difference between public and private acquisitions financed by noncash methods. We suggest instead that the problem of overvaluation may be mitigated in private acquisitions because the bidder can disclose private information to target shareholders, or because target shareholders have a greater incentive to assess the acquirer's prospects carefully.

(b) Long run returns by the acquirers' value and glamour status

Rau and Vermaelen (1998) and Sudarsanam and Mahate (2003) show that long run underperformance in acquisitions of public targets is predominantly caused by glamour acquirers with high market-to-book ratios, and that positive long run returns are associated with value acquirers with low market-to-book ratios. Table 6 reports the abnormal announcement returns and the long run calendar time returns by target type and the acquirer's market-to-book quintile at the beginning of the year of acquisition. Acquirers are classified as value if their market-to-book ratio

26 Since larger monitors are more likely to be created when stock (rather than all noncash offers) is used, we examined the impact of relative size on stock acquisitions only. Our results were materially unchanged by this alternative classification. 
quintile is quintile one (lowest), neutral if quintiles two-four, and glamour if quintile five (highest).

The announcement returns are shown in Panel A of Table 6. Our finding that announcement returns for private targets are larger on average than those for public targets is supported conclusively for both domestic and cross-border bids, since in each category returns to private targets are greater. In domestic acquisitions, public and private glamour acquirers do worst. The picture is more mixed for cross-border acquisitions where value acquirers appear to be the least successful acquirers on average. We now turn to whether these findings are supported in the long run.

Panel B of Table 6 reports the long run post-bid returns. In domestic acquisitions of public targets, glamour acquirers earn significantly negative returns of $-0.84 \%$. This is a continuation of the negative announcement returns and these returns are much lower than the insignificant negative returns of $-0.31 \%$ experienced by neutral acquirers of public targets, and somewhat lower than the insignificantly negative returns of $-0.60 \%$ experienced by value acquirers of public targets. The returns by value, neutral and glamour in acquisitions of private targets are very different. Each of these showed significant positive announcement abnormal returns. In terms of long run returns, glamour acquirers of private targets earn insignificantly positive returns of 0.14\%. Neutral acquirers earn returns that are not significantly different from zero. However, value acquirers earn significantly negative returns of $-0.74 \%$.

In the long run, glamour acquirers of cross-border public targets earn significantly negative returns of $-1.48 \%$. In contrast, the returns in acquisitions of cross-border public targets by value and neutral acquirers are insignificantly positive, being $0.62 \%$ and $0.15 \%$ respectively. Therefore, the market's initial assessment of glamour bidders for public targets appears to be far more realistic in the case of domestic acquisitions than its overly optimistic assessment of their crossborder counterparts. In cross-border acquisitions of private targets, returns for glamour acquirers 
are an insignificantly positive $0.29 \%$. Neutral acquirers earn insignificant returns of $-0.04 \%$.

Value acquirers earn significantly negative returns of $-1.31 \%$.

\section{Insert Table 6 here}

We therefore find that glamour acquirers experience long run negative returns in public acquisitions, but no evidence of this in private acquisitions where instead value acquirers experience negative long run returns. The former finding is consistent with that of Rau and Vermaelen (1998) and Sudarsanam and Mahate (2003), whose explanation is that glamour acquirers suffer from hubris and consequently overpay for their targets. ${ }^{27}$ It has also been argued (Ang and Kohers, 2001) that hubris is much more likely to surface in public acquisitions compared to private acquisitions because of the much higher level of publicity involved. However, if we combine these predictions that hubris is more likely in glamour acquirers and public acquisitions, we would expect to see glamour private acquirers performing worse than value private acquirers, and that is not what we see. Therefore, our evidence overall is inconsistent with these explanations.

(c) Long run returns by the high-tech status of the acquirer and target

To test the internalization theory of cross-border acquisitions, we relate returns in cross-border acquisitions to the technological know-how of both the acquirer and target industries. We categorise industries as high-tech using the classification of Butchart (1987), and compare returns for acquisitions in which bidder and target industries are both high-tech with acquisitions in which bidder and target industries are not both high-tech. For comparison purposes, we also examine domestic acquisitions. Table 7 reports both announcement and post-bid calendar time returns by target type and the high-tech status of the acquisition.

27 We test whether the negative long-run glamour effect is driven by the method of payment, but find no evidence of this. For domestic public glamour noncash acquisitions, the mean CTAR is $-0.78 \%$ whilst for domestic public glamour cash acquisitions, the CTAR is $-1.31 \%$. For cross-border public glamour non-cash acquisitions, the CTAR is $0.20 \%$ whilst for cross-border public glamour cash acquisitions, the CTAR is $2.97 \%$. 
The announcement returns show that in cross-border acquisitions the mean announcement returns for high-tech private acquisitions are significantly large and positive, whilst all other cross-border acquirers have insignificant announcement returns. For all cross-border acquisitions, high-tech acquisitions result in significant returns of $0.90 \%$ compared to $0.07 \%$ in all non-hightech cross-border deals. In contrast, in domestic acquisitions, the announcement returns are very similar for both high-tech and non-high-tech acquisitions.

Panel B of Table 7 reports on post-bid, 36-month calendar time returns. In domestic public acquisitions involving high-tech firms, returns are a significantly negative $-1.45 \%$. When both firms are not high-tech, returns are an insignificantly negative $-0.31 \%$. In domestic private acquisitions, returns are an insignificant $-0.21 \%$ in high-tech acquisitions, and an insignificant $0.01 \%$ in non-high-tech acquisitions. The return in all domestic acquisitions when both firms are high-tech is an insignificant $-0.43 \%$, compared to an insignificant $-0.15 \%$ when both firms are not high-tech. Overall therefore, in the long run we continue to find little difference between hightech and non-high-tech acquisitions when the target is domestic.

We found that announcement returns for cross-border private high-tech acquisitions were significant and positive. Panel B shows that over the long run, this type of acquisition also results in significantly positive returns of $0.82 \%$, whilst non-high-tech acquisitions result in significantly negative returns of $-0.44 \%$. In all cross-border acquisitions involving high-tech firms, returns are a positive $0.64 \%$, significant at the $10 \%$ level. In contrast, all cross-border acquisitions that do not involve both high-tech firms, result in significantly negative returns of $-0.52 \%$.

\section{Insert Table 7 here}

We check whether long run returns are higher in cross-border acquisitions if either (rather than both) the acquirer or the target are high-tech companies. The results (not tabulated) show no evidence of this. Acquisitions by high-tech acquirers of non-high-tech targets result in returns of $0.68 \%$, significant at the $10 \%$ level. Acquisitions by non-high-tech acquirers of high-tech targets earn insignificantly negative returns of $-0.41 \%$. All cross-border acquisitions by high-tech 
acquirers result in insignificant returns of $0.10 \%$ compared to a significantly negative $-0.45 \%$ for non-high-tech acquirers.

The cross-border high-tech acquisitions involve a higher percentage of related acquisitions (58\%) than the cross-border non-high-tech acquisitions (41\%). However, this difference is not driving our results. The results (not tabulated) show that cross-border non-high-tech related acquisitions and cross-border non-high-tech non-related acquisitions both earn significantly negative long run returns of $-0.49 \%$.

Our long run results are consistent with the short run results of Morck and Yeung (1992) who find that acquirer announcement returns are positively correlated with firm level R\&D expenditure. Our results are also consistent with the findings of Morck and Yeung (1991), and Morck and Yeung (2003) who show that firm level R\&D is positively related to the value of multinational companies, but not domestic companies.

(d) Target country effects in cross-border acquisitions

In this section we analyse calendar time returns in cross-border acquisitions by target country groupings based on trade differences, legal differences, cultural differences, and accounting differences. One explanation for the worse average outcome for cross-border acquisitions is the impact of these differences on UK acquirers. This is addressed in this section by examining the impact of the extent of these differences on merger outcomes. The results are reported in Table 8 , for both public and private acquisitions, although the sample sizes for the former are often very small. $^{28}$

\section{Insert Table 8 here}

Our analysis of announcement returns (not tabulated) show that they are zero for North and Central America, but positive for other continents, a result that holds for both public and private acquisitions. For example, acquisitions in Europe, Australia and Oceania, and the rest of the 
world result in announcement returns of $0.47 \%, 0.63 \%$ and $2.40 \%$ respectively. The first and last returns are statistically significant. The long run returns reported in Table 8 show that over the long run, acquisitions in North and Central America, Europe, and Australia and Oceania, result in zero abnormal returns. However, evidence of long run underperformance is found for the small number (30) of acquisitions in the rest of the world, which result in very large negative (although insignificant) returns of $-0.8 \%$. The long run returns to all continents in public acquisitions are large and negative although not significant, which given the small sample sizes is not surprising. This suggests that the market's initial assessment of public acquisitions outside the US is overly optimistic, especially when compared with the more realistic announcement effect with US targets.

To measure the impact of trade policy, government intervention and capital restrictions on returns we employ the Economic Freedom of the World index developed by Gwartney et al. (1996). We take the average country index scores over the years 1985, 1990, and 1995. The scale for our sample ranges from 3.2 (least free) for Brazil to 9.4 (most free) for Hong Kong, with a median of 7.6. We classify any country with a score of 7.6 or less as having low economic freedom, and any country with a score of more than 7.6 as having high economic freedom. The announcement returns to low economic freedom acquisitions is $0.90 \%$ ( $t$-statistic 3.06), whilst the returns to high economic freedom countries is $0.12 \%$ and insignificant. Over the long run, the returns to acquisitions are an insignificant $-0.06 \%$ and $-0.27 \%$ in low and high economic freedom countries respectively. These results suggest that although the measure of economic freedom does have a negative impact on announcement returns it does not have a significant effect on long run returns.

To examine the impact of the target country's corporate governance system, we report returns according to whether the target country's system is the English common law system, the

28 The results for announcement returns are not reported in this table for reasons of brevity. Whenever they are material to our findings, they are reported in the text. 
Scandinavian civil law system, the Germanic civil law system or the French civil law system (La Porta et al., 2000). Acquisitions of targets from countries with the English, Scandinavian, Germanic, and French legal systems earn announcement returns of $0.18 \%, 0.74 \%, 0.35 \%$, and $0.59 \%$ respectively, with only the French return statistically significant. Long run calendar time returns for these countries are $-0.07 \%, 0.64 \%, 0.35 \%$, and $-0.71 \%$ respectively, with only the French return once again being statistically significant. These results are not consistent with the arguments of La Porta et al. (2000), since there is no linear relation between returns and quality of investor protection.

To measure the impact of the national cultural difference between the UK and the target's country, we employ a composite index based on Hofstede's (1991) numerical classifications of four national cultural dimensions. ${ }^{29}$ For each acquisition, we take the difference between the target country and the UK in each of the four cultural dimensions. Our composite index is the summation of these four differences, ${ }^{30}$ which ranges from a low of 22 for the US to a high of 194 for Portugal, with a median of 94 . We classify any country with a score of 94 or less as having low cultural differences, and any country with a score of more than 94 as having high cultural differences. The announcement returns associated with acquisitions in countries with low cultural differences are an insignificant $0.19 \%$, whilst acquisitions with high cultural differences result in significantly positive returns of $0.76 \%$ ( $t$-statistic 2.28 ). However, over the long run post-bid period, the former result in insignificant negative returns of $-0.19 \%$, whilst the latter result in significantly negative returns of $-0.75 \%$. The long run returns shown in Table 8 suggest that the initial 'better the devil you don't know' market expectation is not well founded, and is dramatically reversed over the long run. This is consistent with practitioner surveys, which report

29 The four dimensions are power distance, uncertainty avoidance, individuality, and femininity. Power distance refers to the distribution of power within the organisational system. Uncertainty avoidance relates to a country's level of intolerance for uncertainty. Individualism measures the perception of an individual's relationship with the rest of collectivity. Femininity refers to the primary goals and objectives that societies have for their progress. 
that up to $90 \%$ of unsuccessful cross-border acquisitions experience major, unforeseen, difficulties due to cultural differences (Schoenberg, 2000; and UNCTAD, 1999).

To examine the impact of the target country's accounting standards on long run returns, we employ the categorisation of Bavishi (1993). The scale of this index for the countries in our sample ranges from a low of 36 for Portugal to a high of 83 for Sweden, with a median of 69 . We classify any country with a score of 69 or less as having low accounting standards, and any country with a score of more than 69 as having high accounting standards. For acquisitions in low accounting standard countries, the announcement returns are $0.56 \%$, significant at the $10 \%$ level, whilst for acquisitions in high accounting standard countries, the announcement returns are an insignificant $0.18 \%$. Over the long run post-bid period, the returns to acquisitions in low accounting standard countries are an insignificantly negative $-0.46 \%$, whilst for acquisitions in high accounting standard countries, the returns are somewhat lower, being an insignificantly negative $-0.18 \%$. These results do not provide support for the argument that lower accounting standards result in significantly lower long run returns.

(e) Other determinants of returns in cross-border acquisitions

To test whether the 1986 US tax changes had a positive impact on acquirer returns, we examined returns to acquisitions of US companies both before and after the changes. The results, not tabulated, show that for US acquisitions completed during 1984-86, the announcement returns are an insignificantly negative $-0.33 \%$, whilst for US acquisitions completed during 1987-1998, returns are an insignificant $0.16 \%$. Over the long run, calendar time returns for the former are an insignificant $-0.31 \%$ compared to an insignificant $-0.12 \%$ for the latter. These results provide little support for the argument that increased tax incentives are linked to returns in cross-border acquisitions.

30 Hofstede's classification has been widely used in the management literature, and has been found to influence many aspects of a firm's organisation, systems, and financial performance (Schoenberg, 2000). 
To test the risk diversification motive, we examined whether returns were negatively related to a diversification variable, defined as the five-year pre-acquisition correlation coefficient between the UK equity market index and the target country's equity market index. We classified any country with a coefficient lower (higher) than the median correlation as having low (high) correlation. We found that low correlation countries experience announcement returns of $0.19 \%$, whilst high correlation countries experience announcement returns of $0.44 \%$, which is significant at the $10 \%$ level. The long run post-bid calendar returns for acquisitions in low correlation countries were an insignificant $-0.28 \%$, compared to an insignificant $-0.18 \%$ in high correlation countries. These results provide no evidence that the correlation in bidder and target markets has a negative impact on either announcement or long run returns.

To test whether the strength of sterling relative to the target country currency (at the time of the acquisition) has a positive effect on returns, we subtract the average exchange rate (units of target country currency per pound sterling) for the 1984-98 sample period from the exchange rate for the completion month, and divide this difference by the average exchange rate. As a result, positive (negative) values indicate that sterling is strong (weak) relative to the target currency. The results, not tabulated, show that for acquisitions in which sterling is strong, announcement period returns are an insignificantly positive $0.14 \%$, and for acquisitions in which sterling is weak, returns are a significantly positive $0.40 \%$. Over the long run post-bid period, a strong exchange rate results in insignificant calendar time returns of $-0.23 \%$, a weak exchange rate in insignificant returns of $-0.19 \%$. These results provide no support for the argument that the strength of sterling at acquisition has a positive impact on announcement or long run returns.

\section{(ii) Regression analysis}

Finally, we draw upon the insights from our univariate analysis to explore the combined effect of these factors on acquisition returns. We examine the determinants of both short run and long run bidder returns using multiple regression analysis. For the announcement period regressions 
we employ standard ordinary least squares cross-sectional analysis. For the post-bid returns, we use a Fama-Macbeth time series of monthly cross-sections methodology that controls for the problem of cross-sectional dependence (Andrade et al., 2001). Specifically, we run a crosssectional regression for each calendar month of the sample period, where the dependent variable is the monthly abnormal return. Coefficient values are estimated using the average values of the monthly coefficients, and statistical significance is calculated using their standard deviation. ${ }^{31}$ In Table 9, we present the results of regressions for the samples of domestic public, domestic private, cross-border public, cross-border private, and all acquisitions. Panel A reports the announcement return regressions, whilst Panel B reports the post-bid return regressions.

Our explanatory variables include the variables that the univariate tests above indicated to be of some importance and other control variables, ${ }^{32}$ and are as follows:

Noncash $=$ one if payment is noncash, zero if not

Relative size $=$ transaction value relative to acquirer size

Relative size $*$ noncash $=$ interaction variable between noncash offers and relative size equal to relative size if payment is noncash, zero if cash

Value $=$ one if acquirer's MTBV ratio is in quintile one (lowest), zero if not

Glamour $=$ one if acquirer's MTBV ratio is in quintile five (highest), zero if not

High-tech $=$ one if both acquirer's and target's industries are defined as high-tech by Butchart (1987)

Subsidiary $=$ one if target is subsidiary of another firm, zero if not

Related $=$ one if merging firms are in same 2-digit SIC, zero if not

Acquirer size $=$ market value in millions of sterling at time of merger announcement

31 We also estimated the same regression models using the standard cross-section methodology with the 36-month BHAR as the dependent variable. The results were very similar and our conclusions unchanged by this alternative method.

32 Previous studies have shown that returns in domestic acquisitions are positively associated with each of these characteristics. For subsidiary targets see Fuller et al. (2002), related acquisitions (Megginson et al., 2004), acquirer size (Mitchell and Stafford, 2000), and hostile acquisitions (Cosh and Guest, 2001). 
Competed $=$ one if more than one bidder for target, zero if not

Hostile $=$ one if acquisition is hostile, zero if friendly

Culture $=$ Composite index of cultural differences between UK and target countries, as described in Section 6(i)(d), with larger values indicating increasing dissimilarity

Private $=$ one if target is privately held firm, zero if publicly traded

Cross-border $=$ one if target is non UK firm, zero if UK firm

Insert Table 9 here

The determinants of the announcement returns for domestic and cross-border, public and private, targets are reported in Panel A of Table 9. The findings for the whole sample in Column (5) indicate that announcement returns are positively influenced by noncash methods and private targets, and are negatively influenced by cross-border acquisitions. These results confirm our earlier univariate findings. No other variables are significant.

If we examine domestic private acquisitions further in column (2) we see that the only significant coefficient is the positive noncash variable. The impact of acquisitions of subsidiaries and of companies in related industries is positive, but not statistically significant. The findings for cross-border acquisitions, as shown in columns (3) and (4), reveal nothing of significance for public or private targets.

The Fama-Macbeth regressions for post-merger performance are shown in Panel B of Table 9. If we look first at column (5), which holds the results for the whole sample, several variables are significant. One, private deals have positive influence on long run performance. This result was noted previously in Table 4 and also in announcement returns. This result holds for the separate samples of domestic and cross-border acquisitions also. Two, cross-border mergers have lower returns than those found in domestic mergers, although the significance is modest. Three, noncash acquisitions have significantly lower long run returns than cash mergers. This latter result holds for all domestic but not cross-border samples. Four, the coefficient for relative size 
suggests that smaller targets may be more easily digested than larger targets, but this result only holds for domestic mergers. The combination variable (for noncash and relative size) is positive and significant. Although larger relative size has a negative impact on long run returns on its own, it can serve to offset the potential damage to long run returns in noncash acquisitions. Again, the only broad group for which this does not hold is cross-border acquisitions. Finally, the coefficient for value acquirers is significantly negative for the entire sample but the result is driven by the cross-border private sample.

For the domestic public sample reported in column (1), the coefficient on the noncash variable is significantly negative and the coefficient on the glamour variable is negative, significant at the $10 \%$ level. The coefficient on the hostile dummy variable is significantly positive. For the domestic private sample reported in column (2), the coefficient for the noncash variable is significantly negative, but not as large as in column (1), whilst the glamour variable is again significantly positive.

For the cross-border public sample reported in column (3) only one variable is significant - the glamour variable - and it is negatively related to long run performance. The other control variables and the culture variable are insignificant. However, for the cross-border private sample in column (4) three variables are significant: value, high-tech and culture. ${ }^{33}$ The latter two variables are interesting because they are hypothesised to be especially important in cross-border mergers. The positive influence that firms (acquiring and target) in the same high-tech industry have on long run returns is supportive of the internalization hypothesis. The negative cultural variable indicates that low cultural similarities between Britain and countries of target firms result in lower long run returns for UK acquirers. The significance of the high-tech and cultural variables also holds for the entire sample of cross-border acquisitions (results not tabulated).

33 For the cross-border regressions, we also included dummy variables for the target country's legal system, and continuous variables for the bidder and target country stock market correlation coefficient, exchange rate strength, economic freedom index, and the accounting standards index as specified above. 
The multivariate long run results are similar to the univariate long run results and the conclusions drawn are as follows. The significant difference between private and public acquisitions is robust after controlling for other explanatory variables. Glamour acquirers underperform in public acquisitions but not private acquisitions. Returns in domestic acquisitions of public targets are significantly lower when noncash is used rather than cash. There is no evidence of this in cross-border acquisitions. We find evidence in domestic acquisitions that relative size has a positive impact in noncash acquisitions, but no support for the more effective monitor theory for cross-border acquisitions. In all cross-border acquisitions, national culture differences have a significantly negative impact, whilst high-tech acquisitions have a significantly positive effect. There is weak evidence that cross-border acquisitions experience lower returns than domestic acquisitions, consistent with the evidence of Denis et al. (2002) who show that multinational firms operate at a value discount compared to domestic firms.

Of the control variables, we find that in domestic acquisitions hostile deals perform better than friendly mergers. This is consistent with previous UK evidence, and the argument that hostile acquisitions are carried out for disciplinary motives (Cosh and Guest, 2001). Although the number of cross-border hostile deals is very small, there is no evidence of superior long run returns. ${ }^{34}$ We tentatively suggest that retention of target management is especially important in cross-border acquisitions, due to their local knowledge of the different cultural, legal and regulatory environment. The results also show that acquisitions of domestic public subsidiaries result in higher returns than acquisitions of domestic public non-subsidiaries. ${ }^{35}$ Although the result is weak and does not hold in cross-border public acquisitions, it provides some support for

The coefficients for these variables were insignificant, consistent with the univariate analysis, and were consequently excluded from the regression.

34 The calendar time returns in domestic hostile acquisitions are an insignificantly positive $0.30 \%$, compared to a significantly negative $-0.54 \%$ in domestic friendly acquisitions. The returns in cross-border hostile acquisitions are an insignificant negative $-1.03 \%$, compared to a significantly negative $-0.70 \%$ in cross-border friendly acquisitions.

35 The calendar time returns in domestic acquisitions of public subsidiaries are an insignificant $0.07 \%$, compared to a significantly negative $-0.55 \%$ in domestic acquisitions of public non-subsidiaries. 
the theory that more concentrated ownership in the target results in higher acquirer returns because of factors such as the reduction of asymmetric information in security financed acquisitions. Control variables that did not prove to be significant in explaining long run returns were relatedness, acquirer size, and competed bids.

\section{Conclusions}

We examine the announcement and three-year post-acquisition performance of a sample of over 4,000 acquisitions by UK public firms occurring during 1984-1998. We include acquisitions of both domestic and cross-border targets, and acquisitions of both publicly quoted and privately held targets. This comprehensive sample allows each acquisition type to be directly contrasted with one another, and permits us to reach conclusions on the long run wealth effects of all acquisitions made by public acquirers. We hypothesise that bidder returns in private acquisitions will be higher than in public deals because of three factors: (i) improved due diligence and monitoring by target shareholders; (ii) lack of hubris effects in the bid process; and (iii), the presence of the private company discount in the relatively illiquid market for private firms. We further argue that the relative returns to bidders in overseas, compared to domestic, acquisitions will depend upon the extent to which the gains from internalising synergies from information based assets via geographical diversification are offset by problems of post-merger integration due to cultural dissonance.

Acquisitions of domestic public targets result in significantly negative announcement returns. Acquisitions of cross-border public targets result in zero announcement returns. In contrast, acquisitions of private targets result in significantly positive announcement returns in both crossborder and in domestic acquisitions. For all public acquisitions, returns are significantly negative, but are significantly positive in all private acquisitions. The returns to all domestic and all crossborder acquisitions are dominated by the private acquisitions and are significantly positive. The 
abnormal returns for the 36 months post-merger are significantly negative for both domestic and cross-border public targets. Acquisitions of private targets result in insignificant negative long run returns for both domestic and cross-border acquisitions. Acquisitions of all domestic companies, which include both public and private targets, exhibit insignificant long run returns. Announcement and long run returns in cross-border acquisitions are lower than in domestic acquisitions.

We find that cash dominates cross-border and private domestic acquisitions. The announcement returns show that cash deals are worse than noncash and public targets give lower announcement returns than private acquisitions. The one exception is for domestic public targets, for which the significantly negative announcement returns experienced by noncash acquirers is lower than the zero announcement returns experienced by cash acquirers. The main difference between domestic private and public acquisitions is the worse performance of public targets in noncash acquisitions. Our evidence is consistent with the theory that acquirers offer securities to acquire domestic public targets when the acquirer is overvalued, but in acquisitions of private targets this problem is mitigated because acquirers can disclose private information to the more concentrated target shareholders.

The poor performance of public acquisitions is limited to those made by glamour acquirers, whilst in contrast, glamour acquirers in private acquisitions do not underperform. The lack of publicity surrounding private acquisitions may decrease the likelihood of hubris-motivated takeovers, since acquirers are better able to break off negotiations when it becomes strategic to do so. However, we would still expect to find glamour acquirers performing worse than other acquirers. Instead, we find that in private acquisitions, it is only value acquirers that experience negative long run returns.

Strong support is found in the long run for the internalization motive for cross-border acquisitions. Cross-border private high-tech acquisitions result in significantly positive announcement and long run returns, whilst non-high-tech acquisitions result in significantly 
negative returns. Our conclusion is that technological know-how is critical in the long run success of direct foreign investment through acquisition. Similarly, long run returns are low when cultural differences are greater between the UK and countries of targets. No support was found for other common explanations for cross-border mergers related to differences in legal systems, accounting standards, economic freedoms, taxes, or exchange rates.

The multivariate results are similar to the univariate results. The significant difference between private and public acquisitions is robust after controlling for other explanatory variables. Glamour acquirers underperform in public acquisitions but not private acquisitions. Returns in domestic acquisitions of public targets (and to a lesser degree for private targets) are significantly lower when noncash is used rather than cash. There is no evidence of this in cross-border acquisitions. We find evidence in domestic acquisitions that relative size has a positive impact in noncash acquisitions, but no support for the more effective monitor theory for cross-border acquisitions. In all cross-border acquisitions, national culture differences have a significantly negative impact, whilst high-tech acquisitions have a significantly positive effect. There is weak evidence that cross-border acquisitions experience lower returns than domestic acquisitions. 


\section{Figure 1}

The Number and Value of Domestic and Cross-Border Acquisitions by UK Acquirers, 1969-2001

\section{Panel A: Number of Domestic and Cross-Border Acquisitions}

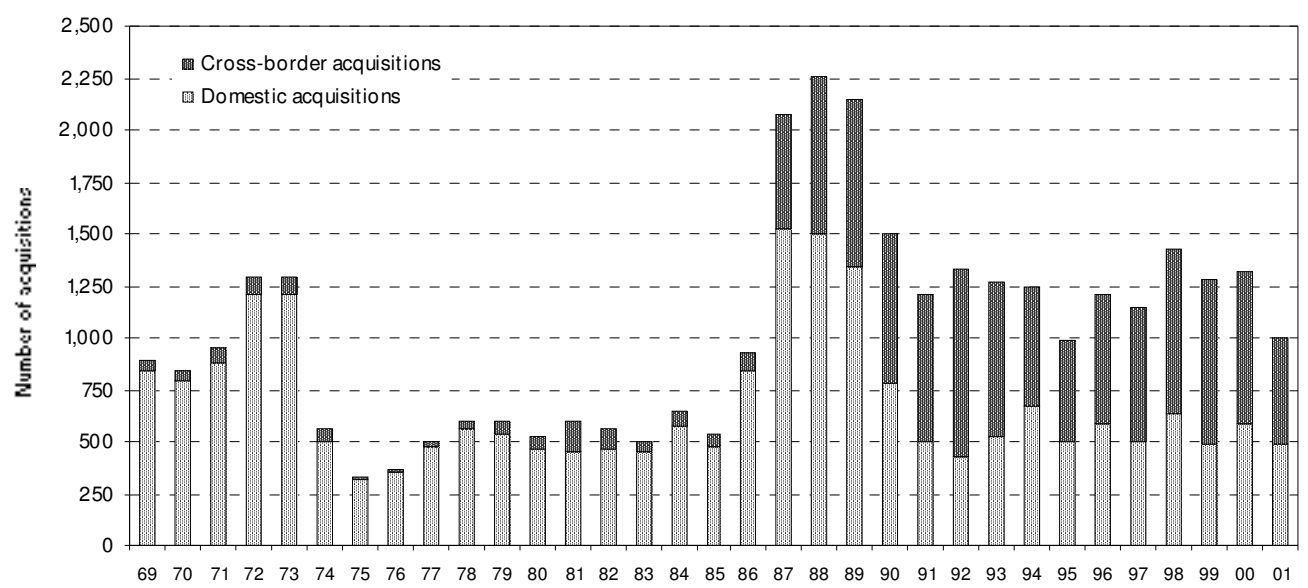

Panel B: Value of Domestic and Cross-Border Acquisitions

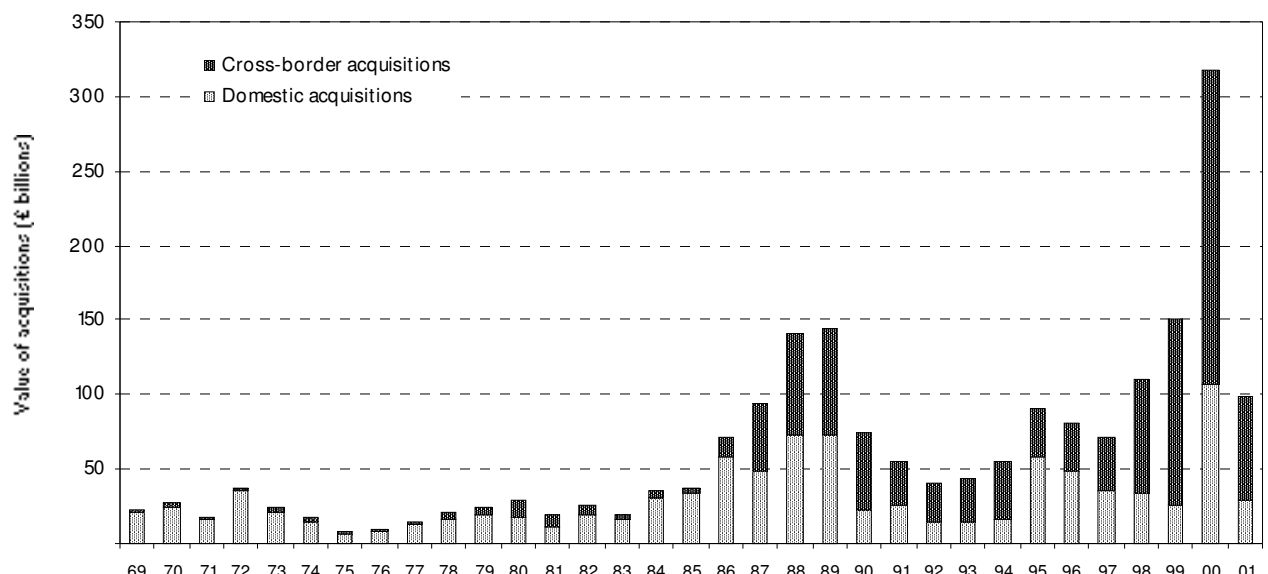

Notes:

Panel A reports the total number of acquisitions made by UK acquiring companies (public and private) of domestic targets and crossborder targets (public and private). Panel B reports the total value of acquisitions made by UK acquiring companies (public and private) of domestic targets and cross-border targets (public and private). The values used are expressed in 2000 sterling values (billions), deflated using the FT All Share index.

Source:

UK Office for National Statistics. 


\section{Table 1}

Summary of the Long Run Event Studies of Acquisitions of Cross-Border Targets and Private Targets

\begin{tabular}{|c|c|c|c|c|c|c|c|c|c|}
\hline Study & $\begin{array}{l}\text { Domestic or Cross- } \\
\text { Border }\end{array}$ & Public or Private & $\begin{array}{l}\text { Bidder } \\
\text { Country }\end{array}$ & $\begin{array}{l}\text { Target } \\
\text { Country }\end{array}$ & Period & $\begin{array}{l}\text { Sample } \\
\text { Size }\end{array}$ & Methodology & $\begin{array}{l}\text { Share Returns } \\
\text { (\%) }\end{array}$ & $\begin{array}{l}\text { Length of Event } \\
\text { Period (Months) }\end{array}$ \\
\hline \multirow{2}{*}{$\begin{array}{l}\text { Conn and Connell } \\
\text { (1990) }\end{array}$} & Cross-border & Public & US & UK & $1971-80$ & 35 & Market model CARs & $-11.5^{b}$ & 12 \\
\hline & Cross-border & Public & UK & US & $1971-80$ & 38 & Market model CARs & $-22.6^{\mathrm{b}}$ & 12 \\
\hline $\begin{array}{l}\text { Danbolt } \\
\text { (1995) }\end{array}$ & Cross-border & Public & Non UK & UK & $1986-91$ & 50 & Market model CARs & $-9.8^{\mathrm{a}}$ & 5 \\
\hline $\begin{array}{l}\text { Eckbo and Thorburn } \\
\text { (2000) }\end{array}$ & Cross-border & Public and private & US & Canada & $1964-83$ & 394 & Market model CARs & -3.7 & 12 \\
\hline $\begin{array}{l}\text { Ang and Kohers } \\
\text { (2001) }\end{array}$ & Domestic & Private & US & US & $1984-96$ & 7,070 & $\begin{array}{l}\text { Fama-French three-factor } \\
\text { model monthly intercept }\end{array}$ & 0.8 & 36 \\
\hline Black et al. (2003) & Cross-border & Public & US & Non-US & $1985-95$ & 361 & $\begin{array}{l}\text { Size/ market-to-book / prior } \\
\text { return portfolio BHARs }\end{array}$ & $-22.9^{a}$ & 60 \\
\hline $\begin{array}{l}\text { Aw and Chatterjee } \\
\text { (2004) }\end{array}$ & Cross-border & Public & UK & Non-UK & $1991-96$ & 41 & Market model CARs & $-24.4^{\mathrm{a}}$ & 24 \\
\hline $\begin{array}{l}\text { Gregory and } \\
\text { McCorriston (2004) }\end{array}$ & Cross-border & Public and private & UK & Non-UK & $1985-94$ & 333 & $\begin{array}{l}\text { Size / market-to-book } \\
\text { portfolio BHARs }\end{array}$ & -9.3 & 60 \\
\hline Moeller et al. (2004) & Domestic & Private & US & US & $\begin{array}{l}1980- \\
2001\end{array}$ & 5,583 & $\begin{array}{l}\text { Fama-French three-factor } \\
\text { model monthly intercept }\end{array}$ & 0.03 & 36 \\
\hline
\end{tabular}


Table 2

Sample Statistics

\begin{tabular}{|c|c|c|c|c|}
\hline & $\begin{array}{c}\text { Domestic } \\
\text { Public }\end{array}$ & $\begin{array}{c}\text { Domestic } \\
\text { Private }\end{array}$ & $\begin{array}{c}\text { Cross-Border } \\
\text { Public }\end{array}$ & $\begin{array}{c}\text { Cross-Border } \\
\text { Private }\end{array}$ \\
\hline Number of Acquisitions & 576 & 2,628 & 131 & 1,009 \\
\hline Number of Acquirers & 403 & 1,146 & 109 & 539 \\
\hline Mean Number of Acquisitions by each Acquirer & 5 & 5 & 5 & 5 \\
\hline Mean Size Quintile of Acquirer & 3.6 & 2.6 & 4.4 & 3.6 \\
\hline Mean Market-to-book Ratio Quintile of Acquirer & 3.0 & 2.8 & 3.2 & 3.2 \\
\hline Mean Size of Acquirer ( $£$ Sterling Millions) & 1,055 & 258 & 2,879 & 1,004 \\
\hline Median Size of Acquirer ( $£$ Sterling Millions) & 211 & 52 & 1,008 & 192 \\
\hline Mean Transaction Value ( $£$ Sterling Millions) & 376 & 49 & 923 & 169 \\
\hline Median Transaction Value ( $£$ Sterling Millions) & 62 & 10 & 266 & 28 \\
\hline Mean Relative Size (Transaction Value to Acquirer) & 0.55 & 0.31 & 0.39 & 0.23 \\
\hline Median Relative Size (Transaction Value to Acquirer) & 0.29 & 0.13 & 0.15 & 0.11 \\
\hline & \multicolumn{4}{|c|}{$\%$ of Acquisitions } \\
\hline \multicolumn{5}{|l|}{ Time Period } \\
\hline 1984-89 & 54 & 32 & 51 & 34 \\
\hline $1990-98$ & 46 & 68 & 49 & 66 \\
\hline \multicolumn{5}{|l|}{ Method of Payment } \\
\hline All Cash & 13 & 54 & 80 & 72 \\
\hline All Stock & 24 & 10 & 8 & 5 \\
\hline Stock and Cash & 50 & 28 & 5 & 15 \\
\hline Other & 11 & 8 & 7 & 8 \\
\hline High-Tech Bidders & 21 & 19 & 27 & 30 \\
\hline High-Tech Targets & 23 & 18 & 36 & 34 \\
\hline Both High-Tech & 8 & 10 & 19 & 21 \\
\hline Hostile Acquisitions & 13 & 0 & 10 & 0 \\
\hline Related Acquisitions & 22 & 43 & 35 & 46 \\
\hline Subsidiary Targets & 24 & 32 & 8 & 39 \\
\hline Competed Acquisitions & 6.4 & 0.4 & 9.9 & 0.5 \\
\hline \multicolumn{5}{|l|}{ Continent of Target for Cross-Border Acquisitions } \\
\hline Australia and Oceania ${ }^{a}$ & & & 8.5 & 4.0 \\
\hline Africa $^{b}$ & & & 0.8 & 0.4 \\
\hline Asia $^{c}$ & & & 1.5 & 0.3 \\
\hline Eastern Asia ${ }^{\mathrm{d}}$ & & & 0.8 & 1.5 \\
\hline Europe $^{\mathrm{e}}$ & & & 17.1 & 42.8 \\
\hline Former USSR ${ }^{\mathrm{f}}$ & & & 0.0 & 0.1 \\
\hline North and Central America ${ }^{g}$ & & & 71.3 & 50.6 \\
\hline South America ${ }^{\mathrm{h}}$ & & & 0.0 & 0.3 \\
\hline
\end{tabular}

Notes:

This table reports summary statistics for a sample of domestic and cross-border acquisitions made by UK public firms between January 1984 and December 1998, where the acquirer was included on the Datastream Database, and where size and market-to-book ratios were available for the end of the last calendar year prior to the year of announcement. Includes only transactions where acquisition value was at least $5 \%$ of acquirer market value at announcement. Market-to-book ratio and size quintiles are calculated by ranking all Datastream firms by market-to-book ratio (or size) at the beginning of each year and taking five groups of equal size in terms of number. Acquirers in quintile one have the lowest market-to-book ratio (or size). Transaction values in foreign currencies were converted to sterling using the exchange rate at the end of the announcement month. The values used are expressed in 2000 sterling values (millions), deflated using the FT All Share index. There are 89 sample acquisitions for which the method of payment is unknown. High-tech companies are those, whose primary SIC code is defined as high-tech by Butchart (1987). Butchart (1987) defines UK industries as high-tech if the R\&D expenditure to industry output is substantially above average. If this ratio is above - but not substantially above - average, a second measure is employed based on the proportion of scientists, professional engineers and technicians in the labour force. Related acquisitions are defined as those in which the acquirer and target share the same primary 2digit SIC code. Subsidiary targets are defined as those in which the target is majority owned by another company. ${ }^{a}$ Australia $(9,35)$, New Zealand $(2,5) .{ }^{\mathrm{b}}$ South Africa $(1,4) .{ }^{\mathrm{c}}$ India $(2,0)$, Pakistan $(0,1)$, Sri Lanka $(0,2) .{ }^{\mathrm{d}}$ Burma $(0,1)$, China $(0,2)$, Hong Kong $(0$, $7)$, Japan $(1,0)$, Malaysia $(0,3)$, Singapore $(0,2)$. ${ }^{\mathrm{e}}$ Austria $(0,2)$, Belgium $(1,24)$, Czech Republic $(0,1)$, Denmark $(0,16)$, Eire $(1$, $12)$, Finland $(1,3)$, France $(6,113)$, Germany $(3,78)$, Greece $(0,1)$, Hungary $(0,1)$, Iceland $(0,1)$, Italy $(0,23)$, Luxembourg $(0,4)$, Netherlands $(4,77)$, Norway $(2,7)$, Portugal $(0,3)$, Spain $(1,27)$, Sweden $(4,24)$, Switzerland $(1,12) .{ }^{g}$ Bermuda $(0,3)$, Canada $(6$, $36)$, Cayman Islands $(0,1)$, Mexico $(0,4)$, Panama $(0,1)$, United States $(86,464)$. ${ }^{\text {h }}$ Brazil $(0,1)$, Chile $(0,1)$, Venezuela $(0,1)$. There are five sample cross-border acquisitions for which the target country is unknown. 


\section{Table 3}

Announcement Period Abnormal Returns

\begin{tabular}{lccc}
\hline & Public & Private & All \\
\hline Domestic & $-0.99^{\mathrm{a}}$ & $1.05^{\mathrm{a}}$ & $0.68^{\mathrm{a}}$ \\
& $(-4.00,575)$ & $(8.70,2,611)$ & $0.33^{\mathrm{b}}$ \\
Cross-Border & -0.09 & $0.38^{\mathrm{b}}$ & $(1.99,1,134)$ \\
& $(-0.19,130)$ & $(2.17,1,004)$ & $0.59^{\mathrm{a}}$ \\
All & $-0.82^{\mathrm{a}}$ & $0.86^{\mathrm{a}}$ & $(6.43,4,320)$ \\
& $(-3.74,705)$ & $(8.64,3,615)$ & $(6,3)$ \\
\hline
\end{tabular}

Notes:

This table reports the mean cumulative abnormal share return (CAR) for acquirers calculated over the announcement period, which is calculated from day -1 to day +1 , where day 0 is the announcement day. The abnormal return is calculated relative to the Market Index. Figures in parentheses are the $t$-statistic and number of acquisitions. ${ }^{\mathrm{a}, \mathrm{b}, \mathrm{c}}$ refers to $1 \%, 5 \%$ and $10 \%$ significance levels. 


\section{Table 4}

Post-bid Abnormal Returns Using Buy-and-Hold Returns and Calendar Time Returns

\begin{tabular}{lccc}
\hline & Public & Private & All \\
\hline Panel A: Buy-and-hold Abnormal Returns & & & \\
Domestic & $-19.78^{\text {a }}$ & -4.78 & -7.47 \\
& $(-2.73,576)$ & $(-0.75,2,628)$ & $-13.37^{\mathrm{c}}$ \\
Cross-Border & $-32.33^{\mathrm{b}}$ & -10.91 & $(-1.80,1,140)$ \\
& $(-2.51,131)$ & $(-1.42,1,009)$ & -9.02 \\
All & $-22.11^{\mathrm{a}}$ & -6.48 & $(-1.47,4,344)$ \\
& $(-3.14,707)$ & $(-1.03,3,637)$ & \\
\hline
\end{tabular}

\section{Panel B: Calendar Time Abnormal Returns}

Domestic

$-0.40^{b}$
$-0.08$

$(-0.55,2,628)$

$-0.19$
$-0.19$

Cross-Border

$-0.71^{b}$

$(-1.20,1,009)$

$-0.27$

$(-2.17,131)$

$-0.14$

$(-1.63,1,140)$

$-0.42^{b}$

$(-1.06,3,637)$

All

$(-2.10,707)$

$-0.21$

$(-1.58,4,344)$

\section{Notes:}

Panel A reports mean buy-and-hold abnormal returns (BHAR) for acquirers over the 36 months following the completion month, computed with respect to control firms matched on size and market-to-book ratio. The $t$-statistics are adjusted for cross-sectional dependence in an identical way to Mitchell and Stafford (2000) as described in the text. Panel B reports mean calendar time abnormal share returns (CTAR) calculated using the acquirer's 36-month post-bid abnormal returns, with reference to control firms matched on size and market-to-book ratio. Calendar months with less than five observations have been excluded from the analysis. Figures in parentheses are the $t$-statistic and number of acquisitions. ${ }^{\mathrm{a}, \mathrm{b}, \mathrm{c}}$ refers to $1 \%, 5 \%$ and $10 \%$ significance levels. 


\section{Table 5}

Announcement Period and Post-Bid Abnormal Returns by Method of Payment

\begin{tabular}{|c|c|c|c|c|}
\hline Domestic / Cross-Border & All Cash / Noncash & Public & Private & All \\
\hline \multicolumn{5}{|c|}{ Panel A: Announcement Period Cumulative Abnormal Returns } \\
\hline \multirow[t]{4}{*}{ Domestic } & All Cash & 0.43 & $0.72^{\mathrm{a}}$ & $0.71^{\mathrm{a}}$ \\
\hline & & $(0.72,75)$ & $(4.98,1,390)$ & $(5.02,1,465)$ \\
\hline & Noncash & $-1.19^{a}$ & $1.41^{\mathrm{a}}$ & $0.63^{\mathrm{a}}$ \\
\hline & & $(-4.40,500)$ & $(6.92,1,165)$ & $(3.77,1,665)$ \\
\hline \multirow[t]{4}{*}{ Cross-Border } & All Cash & -0.19 & 0.27 & 0.21 \\
\hline & & $(-0.37,105)$ & $(1.34,703)$ & $(1.12,808)$ \\
\hline & Noncash & 0.24 & $0.66^{\mathrm{c}}$ & $0.62^{c}$ \\
\hline & & $(0.20,25)$ & $(1.76,268)$ & $(1.74,293)$ \\
\hline \multirow[t]{4}{*}{ All } & All Cash & 0.07 & $0.57^{\mathrm{a}}$ & $0.53^{\mathrm{a}}$ \\
\hline & & $(0.17,180)$ & $(4.83,2,093)$ & $(4.70,2,273)$ \\
\hline & Noncash & $-1.12^{a}$ & $1.27^{\mathrm{a}}$ & $0.63^{a}$ \\
\hline & & $(-4.25,525)$ & $(7.05,1,433)$ & $(4.15,1,958)$ \\
\hline
\end{tabular}

\section{Panel B: Post-bid Calendar Time Abnormal Returns}

Domestic

All Cash

0.06

$-0.14$

$-0.13$

$(0.19,75)$

$(-0.77,1,400)$

$(-0.80,1,475)$

Noncash

$-0.47^{b}$

$-0.07$

$-0.22$

\section{$(-1.97,501)$}

Cross-Border

All Cash

Noncash

All Cash $-0.59^{\mathrm{c}}$

$(-1.65,105)$

$-0.51$

$(-0.92,26)$

$-0.28$

$(-1.03,180)$

$-0.40^{\mathrm{c}}$

$(-1.73,427)$
$(-0.35,1,172)$

$-0.19$

$(-0.79,706)$

$-0.32$

$(-1.20,270)$

$-0.23$

$(-1.452,106)$

$-0.08$

$(-0.43,1,442)$
$(-1.26,1,673)$

$-0.31$

$(-1.29,811)$

$-0.21$

$(-0.80,296)$

$-0.25$

$(-1.61,2,286)$

$-0.19$

\footnotetext{
Notes:

Panel A reports the mean cumulative abnormal share return (CAR) for acquirers over the announcement period, which is calculated from day -1 to day +1 , where day 0 is the announcement day. The abnormal return is calculated relative to the Market Index. Panel B reports mean calendar time abnormal share returns (CTAR) calculated using the acquirer's 36-month post-bid abnormal returns, with respect to control firms matched on size and market-to-book ratio. Calendar months with less than five observations have been excluded from the analysis, except for cross-border public noncash acquisitions, for which all available months were included. In Panels A and B, acquisitions are classified according to the payment method used, categorised as all cash offers, or any other type of offer. The payment method is unknown for 89 acquisitions. Figures in parentheses are the $t$-statistic and number of acquisitions. ${ }^{a}$, b, refers to $1 \%, 5 \%$ and $10 \%$ significance levels.
} 
Table 6

Announcement Period and Post-Bid Abnormal Returns by Acquirer MTBV

\begin{tabular}{|c|c|c|c|c|}
\hline Domestic/Cross-Border & $M T B V$ & Public & Private & All \\
\hline \multicolumn{5}{|c|}{ Panel A: Announcement Period Cumulative Abnormal Returns } \\
\hline \multirow[t]{6}{*}{ Domestic } & Value & -0.77 & $1.35^{\mathrm{a}}$ & $0.99^{\mathrm{a}}$ \\
\hline & & $(-0.93,87)$ & $(3.60,430)$ & $(2.99,517)$ \\
\hline & Neutral & $-0.76^{\mathrm{a}}$ & $1.04^{\mathrm{a}}$ & $0.72^{\text {a }}$ \\
\hline & & $(-2.66,359)$ & $(7.15,1,641)$ & $(5.49,2,000)$ \\
\hline & Glamour & $-1.73^{a}$ & $0.80^{\mathrm{a}}$ & 0.31 \\
\hline & & $(-3.26,129)$ & $(3.48,540)$ & $(1.45,669)$ \\
\hline \multirow[t]{6}{*}{ Cross-Border } & Value & -0.84 & -0.25 & -0.33 \\
\hline & & $(-0.60,19)$ & $(-0.39,120)$ & $(-0.57,139)$ \\
\hline & Neutral & 0.01 & 0.34 & 0.30 \\
\hline & & $(0.03,75)$ & $(1.55,613)$ & $(1.50,688)$ \\
\hline & Glamour & 0.03 & $0.74^{\mathrm{b}}$ & $0.65^{\mathrm{b}}$ \\
\hline & & $(0.02,36)$ & $(2.31,271)$ & $(2.10,307)$ \\
\hline \multirow[t]{6}{*}{ All } & Value & -0.78 & $1.00^{\mathrm{a}}$ & $0.71^{\mathrm{b}}$ \\
\hline & & $(-0.79,106)$ & $(3.07,550)$ & $(2.39,656)$ \\
\hline & Neutral & $-0.63^{b}$ & $0.85^{\mathrm{a}}$ & 0.61 \\
\hline & & $(-2.49,434)$ & $(6.99,2,254)$ & $(5.55,2,688)$ \\
\hline & Glamour & $-1.35^{a}$ & $0.78^{a}$ & $0.42^{b}$ \\
\hline & & $(-2.76,165)$ & $(4.18,811)$ & $(2.37,976)$ \\
\hline \multicolumn{5}{|c|}{ Panel B: Post-bid Calendar Time Abnormal Returns } \\
\hline \multirow[t]{6}{*}{ Domestic } & Value & -0.60 & $-0.74^{b}$ & $-0.71^{b}$ \\
\hline & & $(-1.15,87)$ & $(-2.13,433)$ & $(-2.43,520)$ \\
\hline & Neutral & -0.31 & -0.07 & -0.21 \\
\hline & & $(-1.46,359)$ & $(-0.44,1,651)$ & $(-1.43,2,010)$ \\
\hline & Glamour & $-0.84^{\mathrm{b}}$ & 0.14 & -0.04 \\
\hline & & $(-2.00,130)$ & $(0.41,544)$ & $(-0.17,674)$ \\
\hline \multirow[t]{6}{*}{ Cross-Border } & Value & 0.62 & $-1.31^{b}$ & $-1.27^{b}$ \\
\hline & & $(0.40,19)$ & $(-2.21,120)$ & $(-2.13,139)$ \\
\hline & Neutral & 0.15 & -0.04 & -0.03 \\
\hline & & $(0.39,75)$ & $(-0.18,615)$ & $(-0.13,690)$ \\
\hline & Glamour & $-1.48^{b}$ & 0.29 & -0.14 \\
\hline & & $(-2.20,47)$ & $(1.07,274)$ & $(-0.44,321)$ \\
\hline \multirow[t]{6}{*}{ All } & Value & -0.50 & $-0.85^{a}$ & $-0.94^{a}$ \\
\hline & & $(-0.98,106)$ & $(-2.76,553)$ & $(-3.31,659)$ \\
\hline & Neutral & -0.24 & -0.12 & -0.16 \\
\hline & & $(-1.19,434)$ & $(-0.85,2,266)$ & $(-1.18,2,700)$ \\
\hline & Glamour & $-0.91^{\mathrm{b}}$ & 0.12 & -0.16 \\
\hline & & $(-2.54,167)$ & $(0.39,818)$ & $(-0.60,985)$ \\
\hline
\end{tabular}

Notes:

Panel A reports the mean cumulative abnormal share return (CAR) for acquirers over the announcement period, which is calculated from day -1 to day +1 , where day 0 is the announcement day. The abnormal return is calculated relative to the Market Index. Panel B reports mean calendar time abnormal share returns (CTAR) calculated using the acquirer's 36-month post-bid abnormal returns, with respect to control firms matched on size and market-to-book ratio. Calendar months with less than five observations have been excluded from the analysis. In Panels A and B, acquirers are categorised as value, neutral or glamour depending on their market-tobook (MTBV) quintile at the beginning of the year of acquisition. Market-to-book ratio quintiles are calculated by ranking all Datastream firms by market-to-book ratios at the beginning of each year and taking five groups equal sized in terms of number. Acquirers in quintile one (lowest market-to-book ratio) are defined as value, acquirers in quintiles 2-4 are defined as neutral, and acquirers in quintile five are defined as glamour. Figures in parentheses are the $t$-statistic and number of acquisitions. ${ }^{\mathrm{a}, \mathrm{b}, \mathrm{c}}$ refers to $1 \%$, $5 \%$ and $10 \%$ significance levels. 
Table 7

Announcement Period and Post-Bid Abnormal Returns by High-Tech Status

\begin{tabular}{|c|c|c|c|c|}
\hline Domestic / Cross-Border & High-Tech /Non-High-Tech & Public & Private & All \\
\hline \multicolumn{5}{|c|}{ Panel A: Announcement Period Cumulative Abnormal Returns } \\
\hline \multirow[t]{4}{*}{ Domestic } & High-Tech & $-2.34^{\mathrm{a}}$ & $1.33^{\mathrm{a}}$ & $0.61^{\mathrm{b}}$ \\
\hline & & $(-4.62,119)$ & $(3.78,485)$ & $(1.99,604)$ \\
\hline & Non-High-Tech & $-0.63^{a}$ & $0.98^{\mathrm{a}}$ & $0.69^{\mathrm{a}}$ \\
\hline & & $(-2.22,456)$ & $(7.88,2,126)$ & $(6.08,2,582)$ \\
\hline \multirow[t]{4}{*}{ Cross-Border } & High-Tech & -0.11 & $1.02^{\mathrm{a}}$ & $0.90^{\mathrm{a}}$ \\
\hline & & $(-0.12,35)$ & $(2.90,303)$ & $(2.72,338)$ \\
\hline & Non-High-Tech & -0.11 & 0.10 & 0.07 \\
\hline & & $(-0.20,95)$ & $(0.49,701)$ & $(0.39,796)$ \\
\hline \multirow[t]{4}{*}{ All } & High-Tech & $-1.83^{a}$ & $1.21^{\mathrm{a}}$ & $0.71^{\mathrm{a}}$ \\
\hline & & $(4.02,154)$ & $(4.75,788)$ & $(3.12,942)$ \\
\hline & Non-High-Tech & $-0.54^{b}$ & $0.76^{\mathrm{a}}$ & $0.55^{\mathrm{a}}$ \\
\hline & & $(-2.13,551)$ & $(7.17,2,827)$ & $(5.60,3,378)$ \\
\hline \multicolumn{5}{|c|}{ Panel B: Post-bid Calendar Time Abnormal Returns } \\
\hline \multirow[t]{4}{*}{ Domestic } & High-Tech & $-1.45^{b}$ & -0.21 & -0.43 \\
\hline & & $(-2.02,48)$ & $(-0.60,197)$ & $(-1.42,308)$ \\
\hline & Non-High-Tech & -0.31 & 0.01 & -0.15 \\
\hline & & $(-1.54,528)$ & $(0.08,2,368)$ & $(-1.04,2,896)$ \\
\hline \multirow[t]{4}{*}{ Cross-Border } & High-Tech & -0.59 & $0.82^{\mathrm{b}}$ & $0.64^{\mathrm{c}}$ \\
\hline & & $(-0.80,25)$ & $(2.18,208)$ & $(1.76,233)$ \\
\hline & Non-High-Tech & $-0.61^{\mathrm{c}}$ & $-0.44^{b}$ & $-0.52^{\mathrm{a}}$ \\
\hline & & $(-1.77,106)$ & $(-2.07,801)$ & $(-2.60,907)$ \\
\hline \multirow[t]{4}{*}{ All } & High-Tech & $-1.10^{a}$ & 0.09 & -0.11 \\
\hline & & $(-2.68,73)$ & $(0.28,468)$ & $(-0.40,541)$ \\
\hline & Non-High-Tech & $-0.39^{c}$ & -0.16 & -0.23 \\
\hline & & $(-1.90,634)$ & $(-1.08,3,169)$ & $(-1.62,3,803)$ \\
\hline \multicolumn{5}{|c|}{$\begin{array}{l}\text { Notes: } \\
\text { Panel A reports the mean cumulative abnormal share return (CAR) for acquirers over the announcement period, which is calculated } \\
\text { from day }-1 \text { to day }+1 \text {, where day } 0 \text { is the announcement day. The abnormal return is calculated relative to the Market Index. Panel B } \\
\text { reports mean calendar time abnormal share returns (CTAR) calculated using the acquirer's 36-month post-bid abnormal returns, with } \\
\text { respect to control firms matched on size and market-to-book ratio. Calendar months with less than five observations have been } \\
\text { excluded from the analysis. In Panels A and B, acquisitions are classified according to whether the acquirer's and target firm's primary } \\
\text { industries are both defined as high-tech, according to Butchart (1987). Butchart (1987) defines UK industries as high-tech if the R\&D } \\
\text { expenditure to industry output is substantially above average. If this ratio is above - but not substantially above - average, a second } \\
\text { measure is employed based on the proportion of scientists, professional engineers and technicians in the labour force. Figures in } \\
\text { parentheses are the } t \text {-statistic and number of acquisitions. }{ }^{\mathrm{a}, \mathrm{b}, \mathrm{c}} \text { refers to } 1 \%, 5 \% \text { and } 10 \% \text { significance levels. }\end{array}$} \\
\hline
\end{tabular}


Table 8

Post-Bid Abnormal Returns by Target Country Characteristics

\begin{tabular}{|c|c|c|c|c|}
\hline \multicolumn{2}{|c|}{ Target Country Groupings } & \multirow{2}{*}{$\begin{array}{c}\text { Public } \\
-0.61\end{array}$} & \multirow{2}{*}{$\begin{array}{c}\text { Private } \\
-0.12\end{array}$} & \multirow{2}{*}{$\begin{array}{c}\text { All } \\
0.24\end{array}$} \\
\hline Continent & Australia and Oceania & & & \\
\hline & & $(-0.70,11)$ & $(-0.17,40)$ & $(0.45,51)$ \\
\hline & Europe & -0.61 & -0.17 & -0.04 \\
\hline & & $(-0.90,24)$ & $(-0.62,430)$ & $(-0.15,454)$ \\
\hline & North and Central America & -0.54 & -0.17 & -0.11 \\
\hline & & $(-1.24,92)$ & $(-0.56,508)$ & $(-0.51,600)$ \\
\hline & Other Continents & -1.54 & -0.47 & -0.8 \\
\hline & & $(-0.87,4)$ & $(-0.54 .26)$ & $(-1.04,30)$, \\
\hline \multirow[t]{4}{*}{ Economic Freedom } & Low & -0.55 & 0.38 & -0.06 \\
\hline & & $(-0.76,18)$ & $(0.85,236)$ & $(-0.20,255)$ \\
\hline & High & -0.43 & -0.29 & -0.27 \\
\hline & & $(-1.07,113)$ & $(-1.09,744)$ & $(-1.15,857)$ \\
\hline \multirow[t]{8}{*}{ Legal System } & English Common Law & -0.56 & -0.14 & -0.07 \\
\hline & & $(-1.33,107)$ & $(-0.45,573)$ & $(-0.34,680)$ \\
\hline & Scandinavian Civil Law & -1.57 & 0.53 & 0.64 \\
\hline & & $(-1.44,7)$ & $(0.68,50)$ & $(1.03,57)$ \\
\hline & German Civil Law & -0.91 & 0.39 & 0.35 \\
\hline & & $(-0.44,5)$ & $(0.81,92)$ & $(0.90,97)$ \\
\hline & French Civil Law & 0.31 & -0.55 & $-0.71^{b}$ \\
\hline & & $(0.40,12)$ & $(-1.54,280)$ & $(-2.36,292)$ \\
\hline \multirow[t]{4}{*}{ Cultural Differences } & Low & -0.48 & -0.21 & -0.19 \\
\hline & & $(-1.26,103)$ & $(-0.79,789)$ & $(-0.87,907)$ \\
\hline & High & -0.59 & $-0.69^{c}$ & $-0.75^{b}$ \\
\hline & & $(-0.70,11)$ & $(-1.91,190)$ & $(-2.15,201)$ \\
\hline \multirow[t]{4}{*}{ Accounting Standards } & Low & -0.91 & -0.31 & -0.46 \\
\hline & & $(-0.99,11)$ & $(-0.77,258)$ & $(-1.50,269)$ \\
\hline & High & -0.51 & -0.22 & -0.18 \\
\hline & & $(-1.49,118)$ & $(-0.71,715)$ & $(-0.80,833)$ \\
\hline
\end{tabular}

This table reports mean calendar time abnormal share returns (CTAR) calculated using the acquirer's 36-month post-bid abnormal returns, with respect to control firms matched on size and market-to-book ratio. Calendar months with less than five observations have been excluded from the analysis, except for the public acquisitions for which all monthly observations are included. 'Other continents' include Africa, Asia, East Asia, South America, and the former USS.R. Economic freedom is measured using the method of Gwartney, et al. (1996). The scale of this index ranges from 3.2 (least free) for Brazil to 9.4 (most free) for Hong Kong, with a median of 7.6. We classify any country with a score of 7.6 or less as having low economic freedom, and any country with a score of more than 7.6 as having high economic freedom. The legal system of the target country is categorised according to LaPorta et al. (2000). The cultural difference measurement is a composite index for cultural difference, formed using the sum of the deviations along four cultural dimensions (Hofstede, 1991) of the acquired firm country from the UK, with larger values signifying increasing dissimilarity. The sum of these differences ranges from a low of 22 for the US to a high of 194 for Portugal, with a median of 94 . We classify any country with a score of 94 or less as having low cultural differences, and any country with a score of more than 94 as having high cultural differences. Accounting standards are measured according to the index used by Bavishi (1993). The scale of this index for the countries in our sample ranges from a low of 36 for Portugal to a high of 83 for Sweden, with a median of 69 . We classify any country with a score of 69 or less as having low accounting standards, and any country with a score of more than 69 as having high accounting standards. Figures in parentheses are the $t$-statistic and number of acquisitions. ${ }^{\mathrm{a}, \mathrm{b}, \mathrm{c}}$ refers to $1 \%, 5 \%$ and $10 \%$ significance levels. 
Table 9

Panel A: Regressions of Announcement Period Abnormal Returns

\begin{tabular}{|c|c|c|c|c|c|}
\hline Variables & (1) & (2) & (3) & (4) & (5) \\
\hline & Domestic & Domestic & Cross-Border & Cross-Border & All \\
\hline & Public & Private & Public & Private & \\
\hline \multirow[t]{2}{*}{ Intercept } & 0.57 & $0.44^{\mathrm{c}}$ & -0.96 & -0.21 & $-1.17^{\mathrm{a}}$ \\
\hline & $(0.70)$ & $(1.74)$ & $(-0.88)$ & $(-0.49)$ & $(-3.77)$ \\
\hline \multirow[t]{2}{*}{ Noncash } & -1.15 & $0.72^{\mathrm{b}}$ & -0.10 & 0.10 & $0.59^{\mathrm{b}}$ \\
\hline & $(-1.23)$ & $(2.23)$ & $(-0.05)$ & $(0.19)$ & $(2.40)$ \\
\hline \multirow[t]{2}{*}{ Relative Size } & -0.34 & -0.08 & -0.77 & -0.57 & -0.04 \\
\hline & $(-0.45)$ & $(-0.40)$ & $(-0.88)$ & $(-1.31)$ & $(-0.27)$ \\
\hline \multirow[t]{2}{*}{ Relative Size * Noncash } & -1.52 & 0.44 & 0.78 & 1.02 & -0.62 \\
\hline & $(-0.82)$ & $(0.49)$ & $(0.22)$ & $(0.63)$ & $(-0.96)$ \\
\hline \multirow[t]{2}{*}{ Value } & 0.04 & 0.32 & 0.06 & -0.31 & 0.14 \\
\hline & $(0.06)$ & $(0.96)$ & $(0.04)$ & $(-0.55)$ & $(0.55)$ \\
\hline \multirow[t]{2}{*}{ Glamour } & -0.70 & -0.31 & -0.12 & 0.51 & -0.18 \\
\hline & $(-1.15)$ & $(-0.99)$ & $(-0.10)$ & $(1.22)$ & $(-0.78)$ \\
\hline \multirow[t]{2}{*}{ High-Tech } & -0.76 & 0.44 & 0.79 & 0.70 & 0.40 \\
\hline & $(-0.84)$ & (1.08) & $(0.61)$ & $(1.55)$ & $(1.44)$ \\
\hline \multirow[t]{2}{*}{ Subsidiary } & 0.73 & 0.34 & 1.52 & 0.31 & 0.29 \\
\hline & $(1.24)$ & $(1.23)$ & $(0.81)$ & $(0.81)$ & $(1.45)$ \\
\hline \multirow[t]{2}{*}{ Related } & 1.01 & 0.21 & -0.15 & -0.23 & 0.18 \\
\hline & (1.62) & $(0.86)$ & $(-0.14)$ & $(-0.63)$ & $(0.95)$ \\
\hline \multirow[t]{2}{*}{ Acquirer Size } & 0.00 & 0.00 & 0.00 & 0.00 & 0.00 \\
\hline & $(-0.44)$ & $(0.34)$ & $(1.21)$ & $(0.24)$ & $(1.01)$ \\
\hline \multirow[t]{2}{*}{ Competed } & -0.30 & 0.32 & 0.38 & -0.50 & -0.23 \\
\hline & $(-0.30)$ & $(0.16)$ & $(0.23)$ & $(-0.20)$ & $(-0.31)$ \\
\hline \multirow[t]{2}{*}{ Hostile } & -0.12 & - & 0.15 & - & - \\
\hline & $(-0.15)$ & - & $(0.08)$ & - & - \\
\hline \multirow[t]{2}{*}{ Culture } & - & - & 0.01 & 0.01 & - \\
\hline & - & - & $(0.00)$ & $(1.35)$ & - \\
\hline \multirow[t]{2}{*}{ Private } & - & - & - & - & $1.75^{\mathrm{a}}$ \\
\hline & - & - & - & - & $(6.49)$ \\
\hline \multirow[t]{2}{*}{ Cross-Border } & - & - & - & - & $-0.47^{b}$ \\
\hline & - & - & - & - & $(-2.17)$ \\
\hline Number of Acquisitions & 565 & 2,603 & 127 & 972 & 4,307 \\
\hline Adjusted $\mathrm{R}^{2}$ & 1.67 & 0.18 & -5.33 & -0.16 & 1.26 \\
\hline
\end{tabular}

Notes:

Panel A reports results from cross-sectional ordinary least squares regressions, where the dependent variable is the cumulative abnormal share return (CAR) for acquirers over the announcement period as defined in Table 3. Noncash is a dummy variable which equals one if the method of payment is not an all cash only offer, zero if all cash only. Relative size is the transaction value relative to the acquirer size. Relative size * noncash is equal to the relative size if the method of payment is noncash, zero if all cash only. Value is a dummy variable equal to one if the acquirer's market-to-book ratio quintile is quintile one (lowest), zero otherwise. Glamour is a dummy variable equal to one if the acquirer's market-to-book ratio quintile is quintile five (highest), zero otherwise. High-tech is a dummy which equals one if the bidder and target's primary SIC codes are both defined as high-tech, according to Butchart (1987), zero if not. Subsidiary is a dummy variable equal to one if the target is majority owned by another company, zero otherwise. Related is a dummy variable, which equals one if the bidder and target share the same primary 2-digit SIC. Acquirer size is the market valuation in millions of the acquirer at the acquisition announcement. Competed is a dummy variable equal to one if there is more than one bidder for the target company, zero if not. Hostile is a dummy variable equal to one if the acquisition is hostile, zero if friendly. Culture is a composite index for cultural difference, formed using the sum of the deviations along four cultural dimensions (Hofstede, 1991) of the acquired firm country from the UK, with larger values signifying increasing dissimilarity. Private is a dummy variable equal to one if the target is a private company, zero if public. Cross-border is a dummy variable equal to one if the target is a crossborder company, zero if domestic. Figures in parentheses are the $t$-statistics. ${ }^{\mathrm{a}, \mathrm{b}, \mathrm{c}}$ refers to $1 \%, 5 \%$ and $10 \%$ significance levels. 
Table 9

Panel B: Fama-Macbeth Regressions of Post-Bid Abnormal Returns

\begin{tabular}{|c|c|c|c|c|c|}
\hline Variables & (1) & (2) & (3) & (4) & (5) \\
\hline & $\begin{array}{c}\text { Domestic } \\
\text { Public } \\
\end{array}$ & $\begin{array}{c}\text { Domestic } \\
\text { Private } \\
\end{array}$ & $\begin{array}{c}\text { Cross-Border } \\
\text { Public } \\
\end{array}$ & $\begin{array}{c}\text { Cross-Border } \\
\text { Private } \\
\end{array}$ & All \\
\hline Intercept & $\begin{array}{c}0.44 \\
(0.85)\end{array}$ & $\begin{array}{c}-0.06 \\
(-0.27)\end{array}$ & $\begin{array}{c}6.17 \\
(1.49)\end{array}$ & $\begin{array}{c}0.51 \\
(1.68)\end{array}$ & $\begin{array}{c}-0.42 \\
(-1.46)\end{array}$ \\
\hline Noncash & $\begin{array}{l}-1.57^{b} \\
(-2.44)\end{array}$ & $\begin{array}{l}-0.52^{b} \\
(-2.02)\end{array}$ & $\begin{array}{c}1.28 \\
(0.87)\end{array}$ & $\begin{array}{c}0.01 \\
(0.02)\end{array}$ & $\begin{array}{l}-0.43^{b} \\
(-2.06)\end{array}$ \\
\hline Relative Size & $\begin{array}{c}-0.36 \\
(-0.40)\end{array}$ & $\begin{array}{l}-0.91^{b} \\
(-2.55)\end{array}$ & $\begin{array}{c}1.30 \\
(0.38)\end{array}$ & $\begin{array}{c}0.65 \\
(1.16)\end{array}$ & $\begin{array}{l}-0.50^{\mathrm{c}} \\
(-1.78)\end{array}$ \\
\hline Relative Size * Noncash & $\begin{array}{c}2.09 \\
(1.18)\end{array}$ & $\begin{array}{l}2.09^{\mathrm{a}} \\
(2.75)\end{array}$ & $\begin{array}{c}-9.66 \\
(-1.57)\end{array}$ & $\begin{array}{c}-2.24 \\
(-1.02)\end{array}$ & $\begin{array}{l}1.72^{\mathrm{b}} \\
(2.29)\end{array}$ \\
\hline Value & $\begin{array}{c}-0.55 \\
(-0.98)\end{array}$ & $\begin{array}{c}-0.52 \\
(-1.41)\end{array}$ & $\begin{array}{l}-11.91 \\
(-0.21)\end{array}$ & $\begin{array}{l}-0.92^{c} \\
(-1.94)\end{array}$ & $\begin{array}{l}-0.81^{a} \\
(-2.77)\end{array}$ \\
\hline Glamour & $\begin{array}{l}-0.72^{\mathrm{c}} \\
(-1.93)\end{array}$ & $\begin{array}{l}0.72^{b} \\
(2.44)\end{array}$ & $\begin{array}{l}-1.91^{b} \\
(-2.01)\end{array}$ & $\begin{array}{c}-0.26 \\
(-0.83)\end{array}$ & $\begin{array}{c}0.01 \\
(0.06)\end{array}$ \\
\hline High-tech & $\begin{array}{c}-0.33 \\
(-0.58)\end{array}$ & $\begin{array}{c}-0.05 \\
(-0.17)\end{array}$ & $\begin{array}{c}0.33 \\
(0.30)\end{array}$ & $\begin{array}{l}0.77^{\mathrm{b}} \\
(2.26)\end{array}$ & $\begin{array}{c}0.21 \\
(0.87)\end{array}$ \\
\hline Subsidiary & $\begin{array}{c}0.57 \\
(1.06)\end{array}$ & $\begin{array}{c}-0.01 \\
(-0.05)\end{array}$ & $\begin{array}{c}-1.61 \\
(-0.77)\end{array}$ & $\begin{array}{c}-0.31 \\
(-1.15)\end{array}$ & $\begin{array}{c}0.11 \\
(0.85)\end{array}$ \\
\hline Related & $\begin{array}{c}-0.03 \\
(-0.10)\end{array}$ & $\begin{array}{c}0.12 \\
(0.74)\end{array}$ & $\begin{array}{c}0.17 \\
(0.16)\end{array}$ & $\begin{array}{c}0.09 \\
(0.29)\end{array}$ & $\begin{array}{c}0.07 \\
(0.49)\end{array}$ \\
\hline Acquirer Size & $\begin{array}{c}0.00 \\
(-0.94)\end{array}$ & $\begin{array}{c}0.00 \\
(-0.99)\end{array}$ & $\begin{array}{c}-0.19 \\
(-0.12)\end{array}$ & $\begin{array}{c}0.00 \\
(1.23)\end{array}$ & $\begin{array}{c}0.00 \\
(-0.21)\end{array}$ \\
\hline Competed & $\begin{array}{l}-0.70 \\
(-1.24)\end{array}$ & $\begin{array}{c}-0.53 \\
(-0.33)\end{array}$ & $\begin{array}{c}1.38 \\
(0.99)\end{array}$ & $\begin{array}{c}-0.18 \\
(-0.13)\end{array}$ & $\begin{array}{c}0.11 \\
(0.23)\end{array}$ \\
\hline Hostile & $\begin{array}{l}1.06^{\mathrm{b}} \\
(2.35)\end{array}$ & $\begin{array}{l}- \\
-\end{array}$ & $\begin{array}{c}0.00 \\
(-0.02)\end{array}$ & - & - \\
\hline Culture & - & - & $\begin{array}{c}-0.15 \\
(-1.60)\end{array}$ & $\begin{array}{l}-0.01^{a} \\
(-2.76)\end{array}$ & - \\
\hline Private & - & - & - & - & $\begin{array}{l}0.62^{\mathrm{a}} \\
(2.81)\end{array}$ \\
\hline Cross-Border & - & - & - & - & $\begin{array}{l}-0.30^{\mathrm{c}} \\
(-1.93)\end{array}$ \\
\hline $\begin{array}{l}\text { Number of Acquisitions } \\
\text { Number of Monthly Obs. } \\
\text { Average Adjusted } \mathrm{R}^{2}\end{array}$ & $\begin{array}{l}576 \\
174 \\
1.40 \\
\end{array}$ & $\begin{array}{c}2,628 \\
184 \\
1.06 \\
\end{array}$ & $\begin{array}{l}129 \\
122 \\
0.46 \\
\end{array}$ & $\begin{array}{l}979 \\
174 \\
2.42 \\
\end{array}$ & $\begin{array}{c}4,344 \\
197 \\
0.68 \\
\end{array}$ \\
\hline
\end{tabular}

Notes:

Panel B reports results from a series of cross sectional ordinary least squares regressions that are estimated for each month of the sample period, where the dependent variable is the post-bid monthly abnormal return calculated with respect to control firms matched on size and market-to-book ratios. The reported coefficients are the averages for all months, and their significance calculated using the monthly standard deviation. Monthly coefficients are winsorized at the $1 \%$ level. The reported adjusted $\mathrm{R}^{2}$ are the averages from the monthly regressions. Months including less than 50 observations are excluded from the analysis, except for model (3) for which the small sample size dictates only months including less than 15 observations are excluded from the analysis. Explanatory variables are as defined in Panel A. Figures in parentheses are the $t$-statistics. ${ }^{\mathrm{a}, \mathrm{b}, \mathrm{c}}$ refers to $1 \%, 5 \%$ and $10 \%$ significance levels. 


\section{References}

Agrawal, A. and J.F. Jaffe (2000), 'The Post-Acquisition Performance Puzzle', in G. Cooper and A. Gregory (eds.), Advances in Acquisitions and Acquisitions (Elsevier Science).

Andrade, G., M. Mitchell and E. Stafford (2001), 'New evidence and perspectives on acquisitions', Journal of Economic Perspectives, Vol. 15, pp. 103-120.

Ang, J. and N. Kohers (2001), 'The Takeover Market for Private Companies: The US Experience', Cambridge Journal of Economics, Vol. 25, pp. 723-748.

Aw, M. and R. Chatterjee (2004), 'The Performance of UK Firms Acquiring Large Cross-Border and Domestic Takeover Targets', Applied Financial Economics, Vol. 14, pp. 337-349.

Baldwin, J.R. and R.E. Caves (1991), 'Foreign Multinational Enterprises and Merger Activity in Canada', in L. Waverman (ed.) Corporate Globalisation through Mergers and Acquisitions (The University of Calgary Press).

Barber, B.M. and J.D. Lyon (1997), 'Detecting Long Run Abnormal Stock Returns: The Empirical Power and Specification of Test Statistics', Journal of Financial Economics, Vol. 43, pp. 341-372.

Bavishi, V.B. (1993), International Accounting and Auditing Trends (New Jersey: Princeton).

Black, E.L., T.A. Carnes, T. Jandik and B.C. Henderson, (2003), 'International Accounting Diversity and the Long-Term Success of Cross-Border Mergers', University of Arkansas Working Paper.

Bodnar, G.M., C. Tang and J. Weintrop (1997), 'Both Sides of Corporate Diversification: The Value Impacts of Geographic and Industrial Diversification', National Bureau of Economic Research Working Paper 6224.

Brown, S. and J. Warner (1980), 'Measuring Security Price Performance', Journal of Financial Economics, Vol. 8, pp. 205-258.

Brown, S. and J. Warner (1985), 'Using Daily Stock Returns: The Case of Event Studies', Journal of Financial Economics, Vol. 14, pp. 3-31.

Butchart, R L. (1987), 'A New Definition of High Technology Industries', Economic Trends, Vol. 400, pp. 82-88.

Caves, R. (1971), 'International Corporations: The Industrial Economics of Foreign Investment', Economica, Vol. 38, pp. 1-27.

Caves, R. (1986), Multinational Enterprise and Economic Activity (Cambridge: Cambridge University Press).

Chang, S. (1998), 'Takeovers of Privately Held Targets, Methods of Payment, and Bidder Returns', Journal of Finance, Vol. 53, pp. 773-784.

Child, J., D. Faulkner and R. Pitkethly (2001), The Management of International Acquisitions (Oxford: Oxford University Press).

Conn, R.L. and F. Connell (1990), 'International Acquisitions: Returns to US and British Firms', Journal of Business Finance \& Accounting, Vol. 17, pp. 689-711.

Conn, R.L. (2003), 'International Acquisitions: Review of Literature and Clinical Projects', Journal of Financial Education, Vol. 29, pp. 1-27.

Cosh, A.D. and P.M. Guest (2001), 'The Long-Run Performance of Hostile and Friendly Takeovers: UK Evidence', Centre for Business Research Working Paper No. 215, Cambridge University.

Coutts, A.J., T.C. Mills and J. Roberts (1997), 'Time Series and Cross-Section Parameter Stability in the Market Model', European Journal of Finance, Vol. 3, pp. 243-59.

Danbolt, J. (1995), 'An Analysis of Gains and Losses to Shareholders of Foreign Bidding Companies Engaged in Cross-Border Acquisitions into the United Kingdom', European Journal of Finance, Vol. 1, pp. 279-309. 
Denis, D.J., D.K. Denis and K. Yost (2002), 'Global Diversification, Industrial Diversification, and Firm Value', Journal of Finance, Vol. 57, pp. 1951-1980.

Eckbo, E.B. and K.S. Thorburn (2000), 'Gains to Bidder Firms Revisited: Domestic and Foreign Acquisitions in Canada', Journal of Financial and Quantitative Analysis, Vol. 35, pp. 1-25.

Fama, E.F. (1998), 'Market Efficiency, Long-Run Returns, and Behavioral Finance', Journal of Financial Economics, Vol. 49, pp. 283-306.

Fama, E.F. and K.R. French (1992), 'The Cross-Section of Expected Returns', Journal of Finance, Vol. 47, pp. 427-66.

Fishman, M.J. (1989), 'Pre-Emptive Bidding and the Role of the Medium of Exchange in Acquisitions', Journal of Finance, Vol. 44, pp. 41-57.

Fuller, K., J. Netter and M. Stegemoller (2002), 'What do Returns to Acquiring Firms tell us? Evidence from Firms that make Many Acquisitions', Journal of Finance, Vol. 57, pp.17631794.

Froot, K.A. and J.C. Stein (1991), 'Exchange Rates and Foreign Direct Investment: An Imperfect Capital Market Approach', Quarterly Journal of Economics, Vol. 106, pp. 1191-1217.

Gaughan, P.A. (2002), Mergers, Acquisitions, and Corporate Restructuring (New York: Wiley).

Gregory, A. and S. McCorriston (2004), 'Foreign Acquisitions by UK Limited Companies: Short and Long-Run Performance', Journal of Empirical Finance, Forthcoming.

Gwartney, J., R. Lawson and W. Block (1996), Economic Freedom in the World: 1975-1995 (The Fraser Institute).

Hansen, R.G. and J. Lott (1996), 'Externalities and Corporate Objectives in a World with Diversified Shareholders/Consumers', Journal of Financial and Quantitative Analysis, Vol. 31, pp. 43-68.

Harris, R.S. and D. Ravenscraft (1991), 'The Role of Acquisitions in Foreign Direct Investment: Evidence from the US Stock Market', Journal of Finance, Vol. 3, pp. 825-844.

Hofstede, G. (1991), Cultures and Organisations (London: Harper Collins).

Jaffe, J.F. (1974), 'Special Information and Insider Trading', Journal of Business, Vol. 47, pp. 305-360.

Koeplin, J., A. Sarin and A. Sharpiro (2000), 'The Private Company Discount', Journal of Applied Corporate Finance, Vol. 12, pp. 94-101.

Kelly, J., C. Cook and D. Spitzer (1999), Unlocking Shareholder Value: The Keys to Success Mergers and Acquisition: A Global Research Report (KPMG).

La Porta, R., F. Lopez-De-Silanes, A. Shleifer and R. Vishny (2000), 'Investor Protection and Corporate Governance', Journal of Financial Economics, Vol. 58, pp. 3-27.

Loughran, T. and A.M. Vijh (1997), 'Do Long-Term Shareholders Benefit from Corporate Acquisitions?' Journal of Finance, Vol. 52, pp. 1765-1790.

Loughran, T. and J.R. Ritter (2000), 'Uniformly Least Powerful Tests of Market Efficiency', Journal of Financial Economics, Vol. 55, pp. 361-390.

Lyon J.D., B.M. Barber and C. Tsai (1999), 'Improved Methods for Tests of Long-Run Abnormal Stock Returns', Journal of Finance, Vol. 54, pp. 165-201.

Mandelker, G. (1974), 'Risk and Return: The Case of Merging Firms', Journal of Financial Economics, Vol. 1, pp. 303-335.

Megginson, W.L., A. Morgan and L. Nail (2004), 'The Determinants of Positive Long-Term Performance in Strategic Mergers: Corporate Focus and Cash', Journal of Banking and Finance, Vol. 28, pp. 523-552.

Mitchell, M.L. and E. Stafford (2000), 'Managerial Decisions and Long-Term Stock Price Performance', Journal of Business, Vol. 73, pp. 287-329.

Moeller, S.B. and F.P. Schlingemann (2002), 'Are Cross-Border Acquisitions Different from Domestic Acquisitions? Evidence on Stock and Operating Performance for US Acquirers', Southern Methodist University Working Paper. 
Moeller, S.B., F. P. Schlingemann and R.M. Stulz (2004), 'Firm Size and the Gains from Acquisitions', Journal of Financial Economics, Forthcoming.

Morck, R. and B. Yeung (1992), 'Internalization: An Event Study Test', Journal of International Economics, Vol. 33, pp. 41-56.

Morck, R. and B. Yeung (1991), 'Why Investors Value Multinationality', Journal of Business, Vol. 64, pp. 165-187.

Morck, R. and B. Yeung (2003), 'Why Firms Diversify: Internalization vs. Agency Behavior', in J. Hand and B. Lev (eds.): Intangibles (Oxford: Oxford University Press).

Myers, S.C. and N.S. Majluf (1984), 'Corporate Financing and Investment Decisions when Firms have Information that Investors do not have', Journal of Financial Economics, Vol. 13, pp. 187-221.

Rau, R.P. and T. Vermaelen (1998), 'Glamour, Value and the Post-Acquisition Performance of Acquiring Firms', Journal of Financial Economics, Vol. 49, pp. 223-253.

Schoenberg, R. (2000), 'The Influence of Cultural Compatibility Within Cross-Border Acquisitions: A Review', in G. Cooper and A. Gregory (eds.): Advances in Acquisitions and Acquisitions (Elsevier Science).

Scholes, M. and M. Wolfson (1990), 'The Effects of Changes in Tax Laws on Corporate Reorganization Activity', Journal of Business, Vol. 63, pp. 141-164.

Sudarsanam, S. and A.A. Mahate (2003), 'Glamour Acquirers, Method of Payment and PostAcquisition Performance: The UK Evidence', Journal of Business Finance \& Accounting, Vol. 30, pp. 299-341.

Teece, D.J., G. Pisano and A. Shuen (1997), 'Dynamic Capabilities and Strategic Management', Strategic Management Journal, Vol. 18, pp. 509-34.

United Nations Conference on Trade and Development (UNCTAD) (1999), World Investment Report 1999 (New York and Geneva: United Nations).

United Nations Conference on Trade and Development (UNCTAD) (2000), World Investment Report 2000 (New York and Geneva: United Nations). 